\title{
Cottage Industry Co-Operatives with Applied Folk Art Profile in Hungary after World War II
}

Received: March 2, 2020 • Accepted: March 30, 2020

\author{
Bence Ament-Kovács \\ Institute of Ethnology, Research Centre for the Humanities, Budapest \\ Hungarian and Comparative Folklore Doctoral Program, Eötvös Loránd University, Budapest
}

\begin{abstract}
This study deals with the history of the Hungarian cottage industry co-operatives with applied folk art profile after World War II. Since publications in this topic concerning Hungary are scarce, this framework is dedicated to the circumstances under which these co-operatives which employed a high number of people and operated quite successfully up to the beginning of the eighties, came into existence, their operations and the scope of objects produced by them, which are identified as applied folk art today. Having the economic, political and cultural environment of the Rákosi- (1949-1956) and Kádár-era (1956-1989) in mind, just as well, as the current approach of creators and ethnographers to the activity of the co-operatives.
\end{abstract}

Keywords: applied folk art, cottage industry co-operatives, folk art, Hungarian People's Republic, socialism

\section{INTRODUCTION}

The official interest of the government was preoccupied with the issue of folk art and cottage industry in the second half of the $19^{\text {th }}$ century in Hungary. The Parliament discussed the support of cottage industry in 1877 for the first time and enclosure thereof in the economic life was envisaged from 1891 on. Local embroidery was exploited as cottage industry product in Kalotaszeg (Transylvania, today in Romania) from as early as the 1880s, while members of the Isabella Cottage Industry Association embroidered interior decoration fabrics and articles of clothing with patterns of counties in the Felvidék (now in Slovakia). National Hungarian Cottage Industry Alliance was formed in 1908, and did not only organize the sale of objects, but laid emphasis on the training of the members. The vernacular decorative traditions of certain representative regions (Matyóföld, Kalocsa etc.) have remained in practice between the two World Wars (FLÓRIán 2009:593). Albeit life conditions of the peasantry have been exposed to considerable changes between the two wars, the really radical transformation of lifestyles was imposed on rural population after World War II (FÉL - Hofer 1969; BALOGH 2003; Ö. Kovács 2013). 
Definite distinction should be made in the history of co-operatives after World War II between the periods of the Rákosi vs. the Kádár-era. From 1944 up to the political transition in 1989, Hungary was occupied by military forces, resulting in an unquestionable political influence of the Soviet. Open Communist takeover took place gradually in the few years following World War II. ${ }^{1}$ The period of Soviet influence which followed can be characterized by the names of two dominant politicians, that of Mátyás Rákosi (1949-1956) and János Kádár (1956-1989).

Neither the agrarian reform, nor the new types of rural jobs could provide full employment in the villages. The tendency can be felt that in areas where state farms were established or where heavy industry was settled, the number of cottage industry co-operatives was lower. Among the latter, folk art, applied folk art profile co-operatives were formed more readily in those regions, where nationally known and renowned folk decorative art activities were in place earlier on. Applied folk art at this time included all branches of former folk art and folk decorative art without making any selections (including herdsman wood carving art just as well), and did not make any distinction between it being made occasionally by villagers or pursuing it as specialists. The same cover was given to cottage industry operated in family circles and not attached to any specific qualifications, just as well as the activities which were subject to qualifications and used purchased materials, but were conducted on small scale, since there are some objects of applied folk art which cannot be produced without appropriate technical skills and a properly equipped workshop (FÉL 1975:6; FLÓRIÁN 1992:4-5; GRÁFIK 2006:233; SZILÁGYI 2006:263-274; CSEH 2014:107-138; VEREBÉLYI 2019:219).

As the dictatorship was further developed, a vulgar interpretation of the government decrees regarded many artisans as ' $k u l a k$ ' since they were employees working in the private sector ${ }^{2}$, imposing increased burdens of quota deliveries on them, while the issue of female employment on the national level remained to be solved. This is why cottage industry co-operatives setting ${ }^{3}$ the production of folk art character objects as their profile mushroomed in the first part of the 1950s. Due to their great numbers it has became justified from the perspective of the government to join their activities in terms of economy, social and artistic aspects (LENGYeL 1980:107; AMENT-Kovács 2019a:17).

1 The first general elections after World War II were held on 4 November 1945 in Hungary, won by the Independent Smallholders' Party (FKgP). Yet, upon pressure by the Soviet, a coalition government was formed in which the department of interior was given to the Communist Party. The first unlawful arrests were made in 1947, and subsequently nothing deterred Communists from kidnapping or physical destruction of opponents in the fight for power. United with the Social Democrats, the Mátyás Rákosi led Hungarian Communist Party founded the Hungarian Workers Party (MDP) in 1948, leading to the establishment of the Stalinist type one-party regime step by step: in August 1949 the Parliament adopted the Constitution of the People's Republic. For more see: FöGLEIN 2001.

2 The expression of Russian origin was originally applied to the well-to-do higher segment of peasantry, but it was used as a synonym to exploiters from the 1950s on.

3 Certain co-operatives have been formed under the auspices of an agricultural co-operative as sections, and were later separated as independent entities. On the case of the Sárköz Folk Arts and Cottage Industry Co-operative see: FlóRIÁN 1990:233. For the Tápé Cottage Industry Co-operative See: KEREKES 2014:460. 


\title{
"HOW ARE YOU GETTING ON? - JOKED RÁKOSI. THAT'S ALL RIGHT - JOKED THE PEASANTS BACK"4
}

The first institution dedicated to the unification of the aforementioned co-operatives was the National Cottage Industry Council which operated up to June 1948, to be replaced by the National Cottage Industry Shareholding Company and in 1949 by the Folk Arts and Cottage Industry Company. In the meantime, the Ministry of Local Industry continued to urge the creation of the cottage industry co-operatives (NAGY 1983:7-8). Although a large number of employees flowed into the co-operatives with the various profiles because of the shortage of land, yet consistent working-hour driven employment of employees with a peasant attitude based on practical considerations caused serious concerns to managers in particular during seasonal farm work and winter stockpiling. Long term solution to this conflict was provided by the developing outworker system. The survival of the peasant mind-set seeing land as a merit is indicated by the local rhetoric of the powerful blaming the - sometimes really problematic - difficulties of raw material procurement ${ }^{5}$ on the once rich peasantry:

\begin{abstract}
"Much damage is caused by the machination of the kulaks by soiling the soft rush still in their possession and by burning it as fuel or feeding to the livestock just as much as they can, even though they could do without it (but not the co-operative). They do not want to sell at any price, in other words they do not wish to talk to members of the co-operative intending to purchase..." (Excerpt from the minutes taken on the monthly gathering of a co-operative, 18 August 1952. Quoted by: BЕск 1967:6)
\end{abstract}

As mentioned above, the origins of some cottage industry co-operatives go back to the 19th century however, the period of the Rákosi-regime was characterized by the formation of the large co-operatives, be them agricultural, small-scale, light or cottage industry co-operatives. (Fig. 1-2) It can be seen on the attached Figure No 1 that public records of Hungarian cottage industry co-operatives with (partially or mainly) applied folk art profiles to be found in the Archives open mainly between the years of 1950 and 1955, and while their closure in the years of the Socialist regime is justified primarily by re-organization, they close down permanently predominantly in the period following the political transition of 1989. Planned economy, class struggle and personality cult left a mark on the first years, the most representative event of which - being, at the same time, the most important from the perspective of the cottage industry co-operatives with applied folk art profile - was the $60^{\text {th }}$ birthday of comrade Rákosi ${ }^{6}$. The Institute for Workers Movement furnished opposite to the House of Parliament in the Supreme Court (now Museum of Ethnography) opened its gates on 9 March 1952, the $60^{\text {th }}$ birthday

${ }_{4}$ A commonly known Hungarian joke mocking at the restrictions and authoritarianism of the Rákosiregime.

5 Sometimes the rations handed out were not sufficient and other time the quality was poor in the initial years of the co-operatives. For a case study see: FLóRIÁN 1990:232.

6 Comrade is way how fellows of the same political stance address each other. Title of nobilities were abolished in the Communist Hungary and additionally, the former - in use up to date - official forms of protocol such as my lady, sir, gentlemen, madam were replaced by the terms comrade, womancomrade, eventually colleague, woman colleague. 


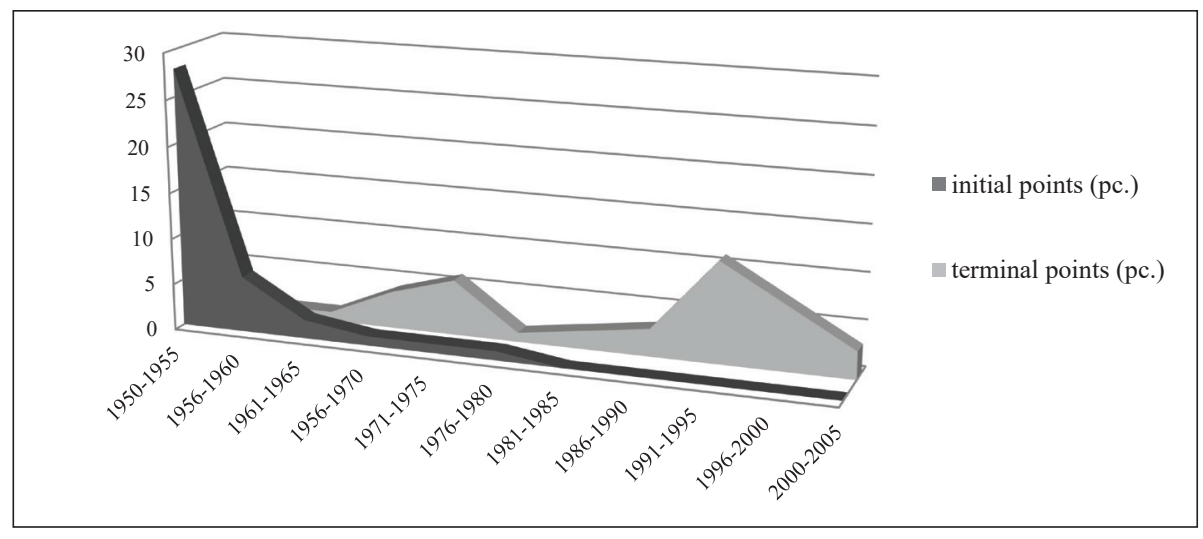

Figure 1. Initial and terminal points of the documents to come across in the archives. Fond intervals do not necessarily cover the period of existence of the co-operatives, but due to the unexplored realm of the co-operatives' history these data provide a safe corner point to my work. Source: BFL XXX.27; BFL XXX.40; BKML XXX.2; BKM XXX.6; BKML XXX.12; BKML XXX.14; BML XXX.8; BML XXX.12; BML XXX.439; BML XXX.440; BML XXX.441; BML XXX.446; BAZML XXX.36; CsML XXX.4; CsML XXX.7; CsML XXX.8; CsML XXX.9; HBML XXX.96; HML XXX.30; HML XXX.33; JNSzML XXX.7; JNSzML XXX.23; JNSzML XXX.24; JNSzML XXX.25; JNSzML XXX.43; JNSzML XXX.46; NML XXX.11; PML XXX.47.a; PML XXX.133.b; PML XXX.141.a; SML XXX.15; SML XXX.16; SzSzBML XXX.82; TML XXX.42; VaML XXX.230; VaML XXX.226; VaML XXX.205, VeML XXX.42.

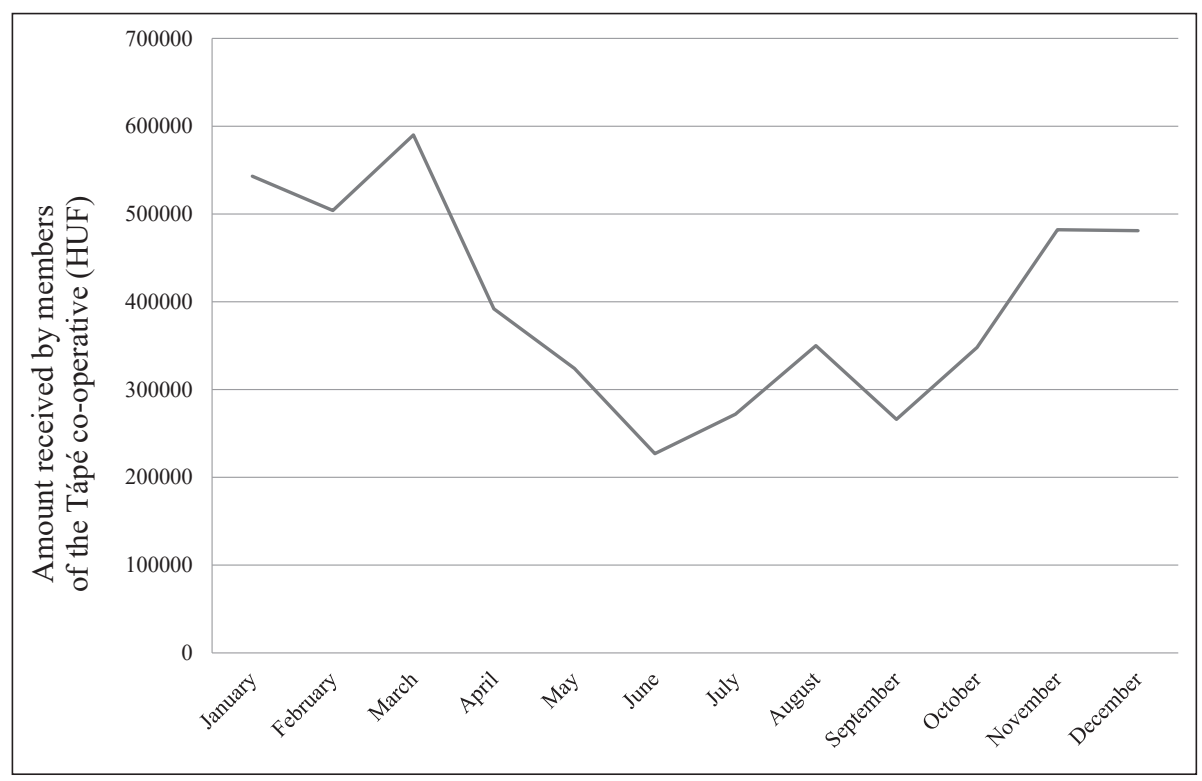

Figure 2. Amounts collected by members of the Tápé co-operative (891 persons) in a monthly breakdown (in HUF), reflecting clearly the influence of the seasonal farming works. Source of figures: KeREKEs 2014:472. (Collected by Antal Juhász, January 1965) 
of Comrade Rákosi, which event basically mimicked the gifting rites of Stalin's $70^{\text {th }}$ birthday. ${ }^{7}$ (Fig. I.1-I.4)

\begin{abstract}
"Attendants gathered from all regions in the country to manifest the deep love of the people (...) only the fresh awareness of human dignity, only the joy of freedom can lend incentives to the making of such objects like the Zala County box, where the arms of the People's Republic of Hungary is inserted among the traditional motives in a full structural harmony on the lid, and the sides feature the symbols of the new life in a sound realistic approach, the life of contemporary rural communities, the agricultural workers conquering nature with the help of the tractor and other modern implements. (...) Folk art souvenirs reflect clearly how a developing political awareness of our people ripens the new form expressing new contents." (LENGYEL 1952:173-174.)
\end{abstract}

As a frequent gesture in the Rákosi era, the portrait of the dictator was posted in public buildings and at state celebrations, but the birthday was a great excuse to combine the portrait with folk art elements, providing the precedent to other creators as well. The event can also be considered as full rehearsal of the Socialist folk art, since the giving of gifts did not only reflect the - albeit strong - pressure from the top, but also gave hints to attempts to opportunism and alignment (KRESZ 1952; FEJÖs 2012:12, 24).

\begin{abstract}
"Socialist folk art is a link between peasantry and the working class - »a gift from the peasantry to the nascent new Socialist culture« - reinforcement to the worker-peasant alliance." (Comment by József Révai on the issue of mass culture at the national convention of the Ministry of People's Education. Quoted by: KRESz 1952:40)
\end{abstract}

A special feature of the term socialist folk art was to expand the formulation of folk art - as a kind of collective art - to the nation as a whole instead of the peasants only, and in conformity with the art concept prevailing in the Soviet Union, the boundaries between applied art and folk art, the folk decorative art became more and more blurred. This is confirmed by the frequently organized exhibitions where the two trades mingled (WEINER 1952:7; SCHUBERT - BALASSA (eds.) 1953:3). The catalogue of the Third Applied Arts and Folk Art Exhibition organised in 1956 was penned by György Domanovszky, who intended to assign the following task to the creators and artists participating at the exhibition:

"The mission of this exhibition is to present those achievements of applied art and folk art from the ten years following the liberation of the nation which enhances the quality the direct environment of the workers in our people's democracy by objects and personal belongings of the grand art." (DomanovszKy 1955:4)

\footnotetext{
7 Museum of Ethnography operating in the same building organized a commemorative exhibition entitled Rakosi60@neprajz.hu on 9 March 2012 and tried to identify the objects included in the original exhibition. The story of the exhibition and the after-life of the objects are told by: Fesös 2012. Catalogue of the original exhibition: BоKOR 1952.
} 
In addition to the more and more creative representations of the dictator himself, Mrs. Rákosi, First Lady of the nation is also found among the ranks of the exhibitors at the Third Applied Arts and Folk Art Exhibition as a specific feature of the personality cult, contributing to the exhibition by porcelain figures. Feodora Feodorovna Kornilova (as her friends called Fenya), a Soviet lawyer of Yakut origin met Mátyás Rákosi in his years spent in emigration and having been married to him followed her husband to Hungary. She got along in friendly terms with Margit Kovács and enrolled the College of Applied Arts in 1948, where István Gádor was the head of the main faculty of ceramics and porcelain and Miklós Borsos a teacher of graphics and modelling. Her classmates found her clearly gifted, albeit State Protection Authority $(\hat{A} V H)^{8}$ visited the institution significantly more often than they used to do otherwise. She took part on the Youth Fine Arts and Applied Arts Exhibition of the National Saloon when she was a second grade student in 1950. After graduation from the school she worked with the Herend Porcelain Factory on several occasions and maybe as a consequence of her personal involvement, the factory could make an exhibition in the Museum of Applied Arts soon (Ifjúsági képzőmüvészeti... 1950:7; PÜNKösTI 2004). A tea service made by her, decorated with the depiction of the Freedom sculpture in Budapest, can be found in the collection of the Museum, with the other pieces decorated by the facilities accomplished during the first five years plan (1950-1954): the ' $7^{\text {th }}$ November' thermal plant of Inota and the depiction of the hydropower plant of Tiszalök. ${ }^{9}$ Beside them, another set commemorates the $10^{\text {th }}$ anniversary of 'liberation of Hungary by the Soviet' in $1945 .{ }^{10}$ In the book entitled Liberated Applied Art Mrs. Mihály Weiner speaks highly of Mrs. Rákosi with the following words:

\footnotetext{
"The new voice of porcelain tableware was sounded primarily by Mrs. Mátyás Rákosi. With the representation of our domestic vegetation she showed a beautiful example of how the artistic achievements of the Soviet Union must be acquired and taken advantage of correctly in the field of our own.” (SCHUBERT - BALASSA (eds.) 1953:30)
}

In the wake of this ardour about Socialist folk art, ${ }^{11}$ the ethnology profession decided to use the term folk applied art in the context of the activities by the fledging co-operatives as a result of the conference held in 1952 in Györ. Also as a consequence of the same meeting, both the National Alliance of Cottage Industry Co-operatives (HISZÖV) and the Applied Folk Arts Council (NIT) were established by Government Decree No 2034/1953 in 1953. NIT President László Nagy defined the concept of applied folk art as follows:

\footnotetext{
"Applied folk art matures to be a dominant notion and becomes an aesthetic category after the liberation of the country. The new genre holds typical aesthetic features and traits. It is different from its predecessor, decorative folk art and is not identical with applied art, either, which was
}

8 The state security organization of the Communist dictatorship in Hungary acting openly in secret during the period between 1948 and 1956.

9 Museum of Applied Arts, inventory registration number: 56.1564.2.1-2

10 Museum of Applied Arts, inventory registration number: 56.1564.1.1-2

11 The study by Mária Kresz referenced here is based on the lecture read out by her on the Györ conference. See: KRESZ 1952. 
born in the end of the last century and unfolded in the present century. Pieces of arts in applied folk art - unlike object of folk art - are not personal belongings in a great part any more, even though there is a great number of such pieces as well, basically, however, they serve aesthetic, decorative purposes. Users of applied folk art products are coming these days mainly from the urban population. And the makers of these objects are professionals, people who earn a living by this activity" (NAGY 1983:6)

An undisputable virtue of the Folk Arts and Cottage Industry Company was that it explored and identified talented creators in the countryside. It has become more and more apparent, however, that professional assistance was needed to continue this work. As a result, the Folk Arts Department of the company was set up and the decree of the Minister for People's Education issued with respect to the branding of folk art articles in 1951 allowed the establishment of a 6 members committee in the company with the task to investigate, whether or not the product is allowed to be marketed. (Fig. II.1-II.2) This committee can be regarded as the forerunner of the Applied Folk Arts Council. This way, professional control was exercised by properly qualified experts instead of the consumer, who held passive knowledge only, or by the tradesmen. According to the aforementioned Decree from 1953, the president of the HISZÖV also held the position of president at NIT, while the head of the HISZÖV Folk Arts Department was also the secretary to NIT (NAGY 1983:8; SzABó 2013:10; VerebéLYI 2019:223). NIT staff - who were not employed by HISZÖV - were recruited from among the personnel on staff of the Museum of Ethnography, country museums, HAS Research group on ethnography and of the Institute for People's Education in addition to the creators of objects, supplemented with art historians, specialists of domestic and foreign trade and representatives of the Ministry of Industry. Due to an intensive growth rate of the objects produced it was not possible for NIT hence after to jury all products itself, therefore a special department of NIT was set up in 1959 (NAGY 1980:77; VARGA 2006:205).

Also in 1953 the title of Master of Folk Arts was founded, a recognition awarded with special liking to natural geniuses, creative staff members, pioneers, who still represented a kind of continuous tradition in folk art, decorative folk art. Their design work determined clearly the appearance of the products manufactured by the cooperatives, their talent being indeed excellent (KRESZ 1952:13; DoMANOVSZKY 1955:15; SzILÁGYi 2005:323). Sometimes their own environment noticed these people. In the 1930s, 1940s for instance, so many women waited for Ilona Zsiga, Mrs. Mihály G. Tóth, an embroideress from Tura, 'discovered' by Marianna Varga to get her patterns on market days, that you could hardly get access to her (BoDroGi 1979:4). Socialist cultural policy dedicated utmost attention to these persons, and put them willingly in representative roles. They appeared regularly in folk costumes and dresses on the obviously pre-arranged typical photographs and on events recorded by newspapers and newsreels. Other countries within the Soviet zone of influence were often interested in them, for instance the Russian film director Vsevolod Illarionovich Pudovkin shot a film on the Hódmezővásárhely potter Mrs. Csenki (WEINER 1952:24). As mentioned earlier, mutual relations were built up, induced by Soviet influence between folk art and applied art. Also in the Soviet model, posing gifted creators of decorative folk art as real artists has become more and more common: 


\begin{abstract}
"Peasantry devotes winter time to repair their buildings, mend tools, prepare spring work, take accounts, enhance culture, and thus the professional village artist who deals with decorative art throughout the year is put more and more in the focus. The role of the decorative folk artist is interpreted in the Soviet Union in this sense. Folk artists in the Soviet Union work in organized collectives, study at colleges, and try to develop their conscious art on an ongoing basis." (WEINER 1952:7)
\end{abstract}

First generation creators have been given outstanding state recognition. Antal Kapoli, a wood carving shepherd received the Kossuth Prize in 1955, and Sándor Kántor potter in 1978, respectively, which is the highest ranking honor of the Hungarian state for pursuing arts. Sándor Kántor was also exhibited as a stand-alone artist in the fall of 1970 in the Kunsthalle.

In the 1950s beside the topics serving the personality cult and praising Mátyás Rákosi's own person and the activities of the Soviet, the application of the themes presenting the mechanization of agriculture, illustrating heavy industry production and expressing the improved quality of life were also dominant on folk art and applied art objects in the spirit of socialist realism. ${ }^{12}$ This tendency can be seen less frequently in the mass production, even though such objects appeared often on exhibitions and representative occasions.

"We have a folk artist in whom the wish to create was triggered by the construction works of the people's democracy. Master József Bezdán creates his wooden inlaid pieces in Pécs (...) the beautiful boxes immortalise the life of contemporary industrial plants, mines, farming co-ops." (WEINER 1952:24) (Fig. III.1-III.4)

Discovery of a creator was a large part the interplay of chance - typical for the epoch and the work of professionals such as an ethnographer, an art historian or an artist, for that matter. The creation of the Orosháza co-operative was encouraged by the fact that pieces of husk works from the Rákóczi-Housing Estate have drawn attention at the agricultural exhibition in 1950 (BECK 1967:4-5). According to another example, art director of the Export Cottage Industry Co-operative seated in Budapest, Klára Heintz visited Tura from 1953 on and founded a section of the co-operative there in 1956. The patterns were designed initially exclusively by the indeed talented Mrs. Mihály G Tóth, got to be known by her. In a few months, however, the number of orders increased to such an extent that her paper based designs had to be reproduced by stencilling. Therefore Mrs. Tóth recommended Julianna Balla for contracting, who joined the embroidery work in 1955 (VARGA 1981:18-19). The peasant furniture painter from Harta, Péter Himpelmann, who was discriminated for his Hungarian German origin, was promoted by Marietta Boross. She was instrumental in the creator being awarded the Master of Folk Art decoration, the extra pension associated with it providing safe livelihood for her informant in his old age, like it did to the respective informants of other ethnographers. (AMENT-Kovács 2017:70)

\footnotetext{
12 According to the interpretation by Máté Major the Leninian way of Socialist Realism consists of the wider propagation of the Socialist ideas the better, while the Stalinian concept advertises a didactic whole of the Socialist contents and national forms. MAJOR 1953:6-8.
} 
Co-operatives of this era could not only have the opportunity to work with the specialists carrying a continuous knowledge and know how, but quite up to the collectivisation surge following the revolution of 1956 they also were in the position to collect authentic peasant art objects, even if their concept on folk art did not always concur with that of the representatives of ethnology. ${ }^{13}$ Pieces of documentation from the collected materials were completed by the 1960s determining the work of the co-operatives active in the textile and fabric based genres (lace, embroidery, hand-woven pieces, costumes) for decades in Decs, Mezőkövesd, Heves, Kalocsa, Kiskunhalas, Siófok (processed embroidery from Karád). The most in-depth exploration was the documentation by Mrs. Dajaszászy Vilma Dietz from Mezökövesd and the hand-woven pieces documentation by Mrs. Béla Tompa from Heves. One copy of the documentation was filed on the archives of the Museum of Ethnography, another in the files of the regionally competent co-operative, and yet another in the NIT archives. (VISZÓCZKY 2003:668)

Next the design and implementation phase of the work followed, since most frequently it was not an old object copied without changes, but new pieces were designed using the treasure of old patterns, designs, or they were taken as an inspiration. For instance, creators in the Cottage Co-operative Industry of Heves-region led by Mrs. Béla Tompa conducted an excessive collection work in their respective region. Hand-woven towels and cushion ends were collected from Átány, Mátraballa and Mátraderecske, embroidered table cloths, tent linen and camisole patterns were taken from Recsk and Bodony. Subsequently the women in the co-operative created the Heves hand-woven pieces as they are known today by the joint application of the picked motives from Átány and the stripe rhythms from the Mátra (BÁDER 2004:461).

Beside Mrs. Tompa, the figure of László Tamás also illustrates clearly how the work of an emblematic person might influence the activity of a co-operative over decades. László Tamás was appointed to the art director of the co-operative of Kaposvár in 1952, where he continued to make Sárköz ceramics, a style he pursued earlier on, and due to his specific field of interest Kaposvár has become a centre of Post-Habanese (in this case: Hungarian Hutterites) ceramic manufacture by the 1970s (KAPITÁNY 1998:4-6). Anikó Füvessy notes with respect to the Middle Tisza region that Karcag has became an important hub in the potter applied folk art of the Nagykunság in the 1950s, increasing this central position by Cuman embroidery and the bone-lace making sites formed after World War I gradually. Basket weaving operations of the region remained active just as well, but the crafting of long standing historical painted joinery of Karcag, Tiszafüred and Kunhegyes was not seen desirable on the long run by the opinion leaders of the cooperative, therefore this genre became extinct in the region (FÜVESSY 2004:407-413). (Fig. IV.1-IV.4)

In certain regions the NIT and the county museums interfered more effectively in the selection of the design patterns and the types of objects to be made. The movement at NIT preserving folk art was inspired primarily from the materials in the middle of the 1800 s, which was classical folk art by all means, confronting the creative communities of those regions (such as Mezökövesd, Sióagárd, Kalocsa), where the forerunners of the

13 On the relationship between the periods of collectivization and peasant art objects see: FéL HOFER 1969. 
applied folk art have emerged as early as at the turn of the $19^{\text {th }}$ and $20^{\text {th }}$ century, ${ }^{14}$ and who, for obvious reasons, looked at direct predecessors as role models, with a difficult situation (BALASSA 1980:23-24; RoMSICS 2003:29-39). Interferences with archaic weaving traditions by strong hands were common in other parts of the country, such as in the case of the Šokci of South Hungary:

\begin{abstract}
"Of them, before all, Mrs. Mihály Borbás from Lakócsa must be distinguished, who created quite new composition arrangements using the rich and diverse local hand-woven elements and those from the surroundings, insisting to the old red and black colour schemes throughout. (...) The world of hand-woven pieces of Mrs. Márk Maticsányec from Alsószentmárton is quite different. Patterns align against black or white background in a diversity of colours. The works by Mrs. Borbás could be posted in any modern interior, but not those of Mrs. Maticsányec. The designer will have to face a serious challenge in recreating the past resting on the traditions." (DoMANOVSZKY 1983:22-23)
\end{abstract}

\title{
"IT'S NOT THE FRENCH ROLL WHICH IS SMALL, COMRADES, YOUR MUG IS TOO BIG!"”15: THE KÁDÁR-ERA
}

By 1958 object were created in 172 premises of 19 cottage industry co-operatives with applied folk art profile, while the production volume - albeit sometimes associated with extremely volatile financial figures - kept on rising (NAGY 1983:11). Production value in the Matyó Folk Arts and Cottage Industry Co-operative was raised by 1961 from the HUF 2,87 million at the time of establishment to HUF 15,71 million over a period of ten years. The number of the employees was increased manifold, too, 1248 people worked in the co-operative as opposed to the initial headcount of 555, their work was supported by a proprietary kindergarten and nursery of the co-operative, in addition to factory medical consultancy expanded to cover outworkers as well (KóRó 1961:36, 40-41). The Palóc Folk Arts Co-operative was founded by 11 persons, and within a period of 10 years 221 people worked for this co-operative (REZNICSEK -VINCZE 2002:8). In Tápé, nine persons founded the Tápé Cottage Industry Co-operative in a classroom of the school on 25 August 1951 , and the number of personnel grew to 341 within a single year, 1100 by 1960, and in 1971, as the second largest co-operative of the country, they employed 2000 persons (the recorder with 2772 workers was at this time the Matyó co-operative) (KEREKES 2014:465-467). The Folk Arts and Cottage Industry Company operated business premises at 5 locations in Budapest alone and at 13 county seats in the year of 1953 (as well as a few temporary pavilions at the Lake Balaton-side), their number has grown to 57 permanent and 18 seasonal shops by 1961. The Commodity Trade Department disposed of the inventories on stock with a view to the orders placed by the shops (SCHNEIDER 1985:54). (Fig. 3)

14 Matyó embroidery is distinguished in periods of the old style (from the $17^{\text {th }}$ century to beginning of the $19^{\text {th }}$ century), the peasant style (19 $9^{\text {th }}$ century) and the newest style of the beginning of the $20^{\text {th }}$ century, featuring some traits of the cottage industry, which cannot be seen entirely as folk industrial art, however (VARGA 2006:116).

15 A statement allegedly made by György Marosán, a Communist politician who was trained as a baker apprentice (BÁRÁNY 2017:36). 


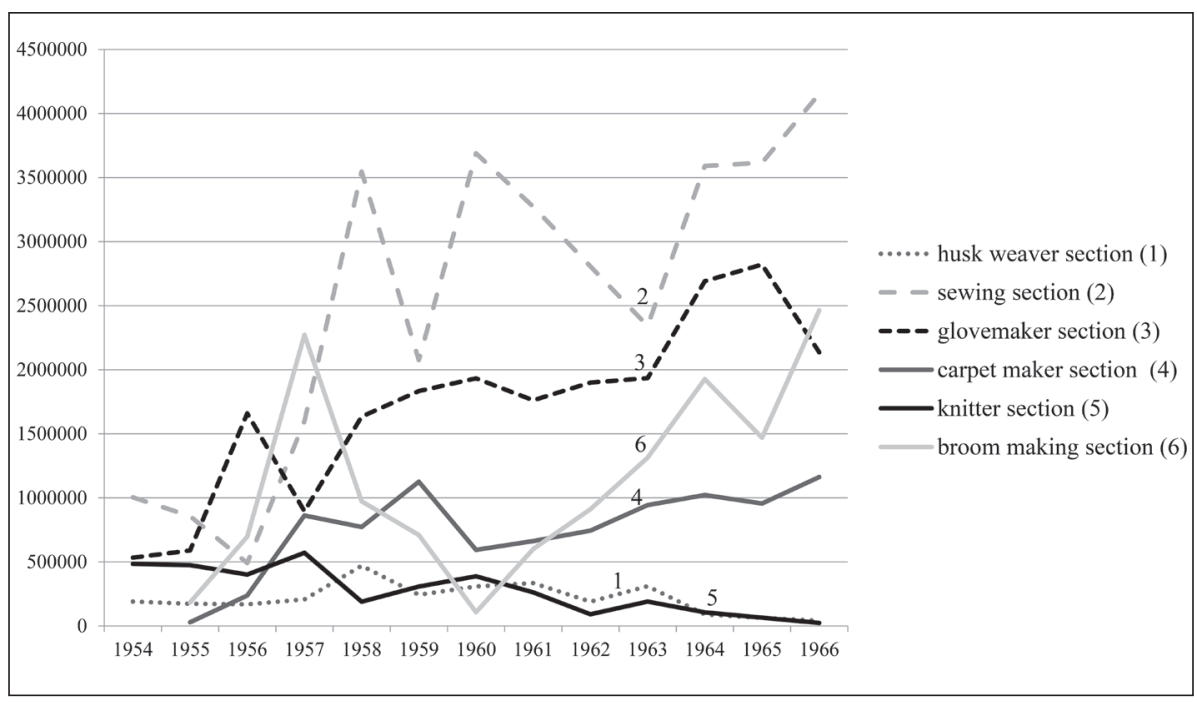

Figure 3. Annual production value of individual sections (HUF) in the Orosháza and Environs Cottage Industry Agricultural Co-operative. Source of figures: BECK 1967: Annexes II.a. - II.b.

In parallel with this training for employees has become necessary because Marianna Varga - on staff at the Folk Arts (later People's Education) Institute at the time - noticed that the first generation who had actual practical know-how about folk art, decorative folk art, started to retire due to their ages (at this time all women retired at the age of 55 in Hungary), and this impaired the artistic value of the production activities carried out in the co-operatives. This is why the first training courses have been started for artists of the co-operative back in 1958, and trainings were conducted to county and district folk art responsible at 12 locations in the countryside up to 1970. In the next phase the Folk Arts Academy was called into being, which in fact assisted to broaden the professional skills and competence of the creators and other interested parties with its lectures in the form of an open university. ${ }^{16}$

László Nagy, former President of the NIT, described the year of 1958 as a palpable daybreak of a new epoch. ${ }^{17}$ Not only because this was the year when an independent folk art (applied folk art) exhibition was first organised without the involvement of classical applied art objects, but also because co-operatives were subject to a generation shift and on top of all that, national power politics experienced a sharp U-turn. Second generation creators could get a fair share from the Applied Folk Arts Fund, operated from an amount equalling to 10 per cent of annual profits made by the cottage industry co-operatives

16 VARGA 1980:115-124. Due to limitations to size I have no opportunity to dwell upon the training of special interest group leaders started within the scope of the Institute for People's Education later more in detail. See more in: BESZPRÉMY 2004:467-476.

17 László Nagy NIT president divided up the history of the applied folk art in 1983 as follows: 1: 1945-1953, before the NIT was founded. 2: 1953-1958, creation of both NIT and HISZÖV until the first folk art exhibition. 3: 1958-1968, wide spread propagation. 4: 1968-1982, applied folk art in the era of the new economic mechanism. 5: 1982-, reorganization of the NIT after transformation of the co-operative system. See: NAGY 1983:6. 
initially (this amount becoming lower at later years), and was used to establish local heritage museums with folk art profile, ${ }^{18}$ compile specialised libraries, award making to artists on competitions, and to assist applied folk artists financially (NAGY 1983:10).

The revolution of 1956 and János Kádár taking power represented arguably a watershed from historical aspects, in fact concurring with the daybreak of a new era in the history of co-operatives mentioned by László Nagy. From the events occurring in the course of the 1956 revolution and the demise of his predecessor, Mátyás Rákosi János Kádár has drawn the conclusion that the Communist system can only be kept up in Hungary without violence if you consolidate the dictatorship and keep on raising the standard of life for all. The so called new economic mechanism, hallmarked primarily with the names of Rezső Nyers and Jenö Fock was a comprehensive reform plan to revamp economic management in a Socialist Hungary, the introduction of which was commenced in 1968. This reform was geared up to reduce the role of central planning and enhance corporate autonomy in the field of investment projects and the production of certain goods. Parallel reform plans were born in 1968 in Czechoslovakia similar to the Hungarian ones, where - just like in the case of our homeland - personal changes took place, Alexander Dubček stepping in the shoes of Antonín Novotný as the first secretary of the Czechoslovak Communist Party. His election resulted in economic and political détente in the hope of creating a human-faced Socialism. The Prague spring ended in August 1968 when the troops of the Warsaw Treaty ${ }^{19}$ marched into Czechoslovakia and the Soviet stood Gustáv Husák to take command of the state, blocking any independent political tendencies of government this way. Naturally, you didn't have to wait for long before reforms had to be stopped in our country as well, Leonyid Brezsnyev, Chief Secretary of the Central Committee in the Communist Party of the Soviet Union exerted pressure on János Kádár also. Therefore, a new economic policy direction unfolded from the 1970s on, which ensured a constant increase of the standard of living by taking out loans instead of a reformed production structure, thereby blowing up the state debt (BROWN 1979:151-155; VALUCH 2013:68-69; RAINER 2014).

'What if' - a question even economic historians would have difficulties to answer in connection with the cottage industry co-operatives with applied folk art profile. One thing is sure, the reform measures bore most fruit in the field of agriculture, where a substantial increase of the standards of living occurred as agricultural production cooperatives became more autonomous and household farming has been endorsed (VARGA 2018). Had prices been formed in the cottage industry production with applied folk art profile indeed to reflect market demand, and had the central wage system been more flexible, it might have lead to the improvement of the financial indicators as a whole, but it would have accelerated all the things which have happened to the co-operatives in the 1980s. (Fig. 4) The position of exactly those outworker employees would have become uncertain, who had difficulties to find their place on the labor market anyway, whether due to their domicile, or as single mothers, women caring for older relatives or being disabled in one respect or other. Their employment was an unquestionable success story

\footnotetext{
18 The first local heritage museums with folk art profile were set up on Mezőkövesd, Kalocsa, Tápé, Hódmezővásárhely and Decs. AmEnT-Kovács 2019a:18.

19 The military organization of the socialist countries in Central and Eastern Europe operating up to 1991.
} 


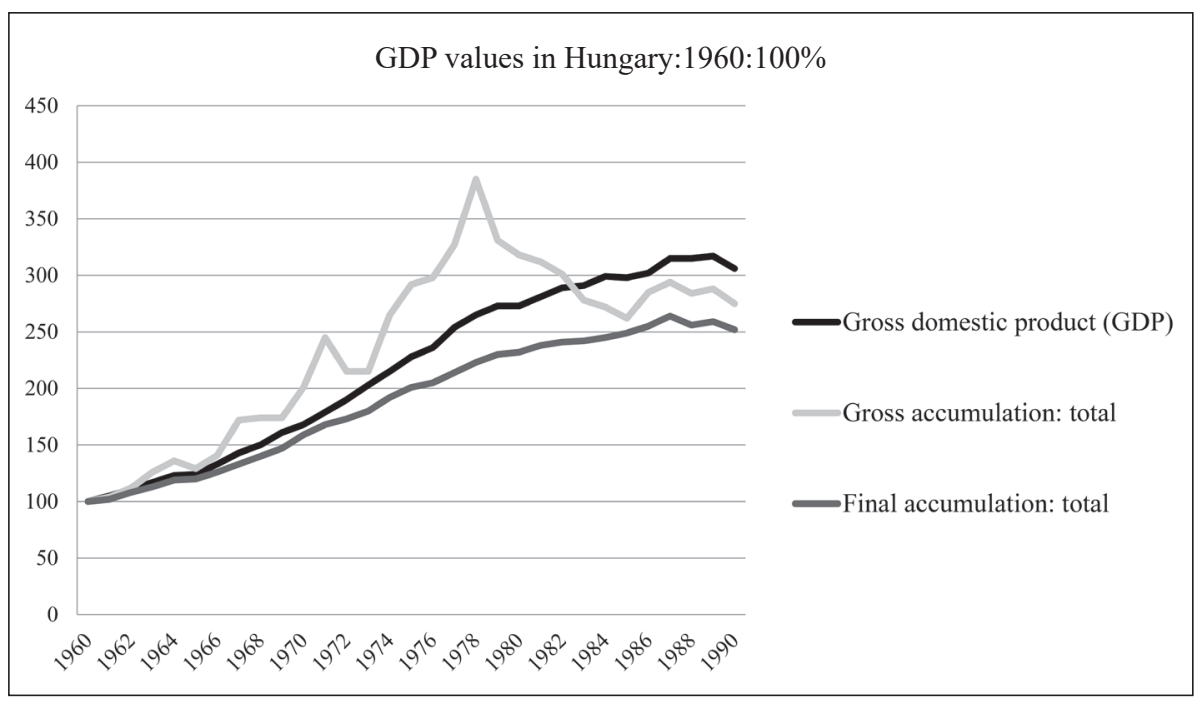

Figure 4. GDP in Hungary, 1960-1980. (1960:100\%) Source of figures: KSH tables (STADAT) Long term data series. 3.1.1. Gross domestic product (GDP) http://www.ksh.hu/stadat_hosszu (accessed January 20, 2020)

of the development of the co-operative system. At any rate, constant growth occurred in terms of profits at the co-operatives quite up to the beginning of the 1980s. Not only fortunate economic decisions boosted success, but the free hand talented designers were given, who took this position as qualified and properly trained fine or applied artists, also played a role. A generation grew up after World War II who thought differently than their predecessors. Albeit no revolutionary movements broke out in the Socialist block like among the youth of Paris, representatives of culture and intelligentsia raised their voices primarily against the intervention in Czechoslovakia, but any such attempt was crushed by strong hands. Let's illustrate this statement with the lines by Ágnes Heller who stood up in defense of Czechoslovakia at the Korčula summer university publicly (and who was deprived of her job in the HAS Sociology Research Group in 1968):

\footnotetext{
"Something important is still happening in Hungary in the year of 1968, something, which will never be included in the annals of history. (...) Any song from members of the Illés band were seen and comprehended as a protest song. Whatever they were about literally, we interpreted them this way, because they provided an opportunity for us to think about 'the thing', i.e. oppression. Lines like »I will never be a killer of my brothers « (I'm not sure I quoted accurately), expressed this attitude directly (...).” (HeLLER 2000:565)
}

Although the reform efforts have been checked, something has changed in culture nevertheless. György Aczél has become a chief culture politician, the dictatorship remained palpable, yet the overwhelming application of the authoritarian symbols, a typical feature of the Rákosi-system was discontinued, and the widening scope of starting materials allowed for the co-operatives to serve the changing social needs and life conditions. (Fig. V.1-V.5) Thanks to the new generation, objects with harmonizing colors 
and forms could also be produced in addition to the souvenirs and decorative items still in demand as status symbols, creators and designers were allowed to assume responsibility for their more creative ideas and to enliven production this way. Obviously, a new era was started. Even the position taken by György Domanovszky was mellowed: "Nordic and Baltic states demonstrate fair examples of how modern, state-of-the-art applied art might be a trigger to applied art with a national character." (DomanovszKy 1973:4)

A specific feature of this period was that mostly properly trained applied artists were employed as lead designers instead of the creators representing the continuous traditions. To highlight some examples from the weaving trade, Ildikó Ardai was employed by the Békésszentandrás Carpet Weaving Cottage Industry Co-operative in 1968 as a career starter, Margit Kányási Holb became a designer at the Debrecen Cottage Industry Cooperative from 1974 until 2002, while Katalin Landgráf fulfilled the same position between 1982 and 1996 at the Cotton Fabric Company (AMENT-KovÁcs 2019b:686).

A new generation was raised not only among co-operative artists. In the second half of the 1970s the Nomad Generation entered the stage, and beside the dance house movement the Young Folk Artists's Studio was launched, uniting, in fact, the talented young artisans of the period, with the urban youth in great numbers into a single group (BALOGH - FÜLEMILE 2008:43-62; FüLEMILE 2018:56-57; JuHÁsz 2018:273-294). The program of integrating the folk art heritage into the national culture was not something quite new to the Socialist cultural policy making, therefore this group - in spite of overtones of dissidence - was not compelled to exist as an underground movement. Young people were divided in two groups along their different approaches. The representatives of the first concept tried to integrate the wealth of folk art motives into Grand Art, they were mainly applied artists, while others thought they had the opportunity to act within the framework of classical folk art. Another feature of the movement was the desire to return to the 'ancient origins'. Some achieved this by simplifying forms, others explored archaic traits not directly connected to Hungarian peasantry. A few members of the group considered folk art as a living phenomenon in the 1970s, 1980s, and there were creators, who thought their movement in contrast to the official one - that is, in this case the applied folk art - was the real successor of folk art (SzILÁGYi 2005:325-326). This early difference in opinions, emerging at the time when the foundations of the folk art movement were laid, declared the dispute, surviving up to this very date, about the nature and living state of folk art. The technical terms of folk art were and are still seen by ethnographers mainly from their historical, typological, structural and functional aspects. However, the emerging population of creators related to the issue emotionally and defined the term folk art along aesthetic qualities (VEREBÉLYI 2002:25-35; SZULOVSZKY 2017:239; Ament-Kovács 2019a:22; CSEH 2020).

An excellent example was the discussion unfolding on the pretext of the folk art of the counties around a demijohn woven with plastic threads. Pál Bánszky art historian criticised János Bencsik ethnographer, because he encompassed this type of objects into his study. ${ }^{20}$ János Bencsik selected - and rightly so, in my mind - the objects included

20 BENCSIK 1997:63 ; BÁNSZKY 2004:374. Kincső Verebélyi excellently summarizes the image drawn up on folk art in the series of county folk art (Our Folk Arts Heritage) in her study, or, more precisely, the opinion of the trade of ethnology about folk art. Contents of the volumes are standard in terms of their structure, but not the concept and idea specialists formed about folk art pieces (VEREBÉLYI 2003:25). 
in his paper based on typological and functional approaches, while Bánszky composed his criticism primarily along aesthetic criteria in line with the approach taken by the Young Folk Artists's Studio. And the fact that plastic coated wires (often electric cables) replaced wickerwork on glass objects in Borsod-Abaúj-Zemplén County in response to the national tendency was called regrettable. In connection with this dispute about interpretations of the concept the aversion of contemporary representatives of folk art museology against objects of applied folk art should be noted. Museologists of the Museum of Ethnography shrunk not only from including objects with symbols alluding to the open personal cult into the inventory in 1952, but in many cases co-operative objects just as well. Objects produced by emblematic creators of regional co-operatives can be often found in county museums as local values and features, but sometimes they have not been even catalogued in the Museum of Ethnography, they were/are kept on record in separate documentation as new folk art objects. Entering certain objects in the stock list was justified by the fact that early objects discharged from co-operatives and pieces of folk art masters document the late period of traditional objects (FEJös 2012:34, 40). (Fig. 5-6)

In the new period of applied folk art publications became more frequent beside wide ranging dissemination of information by the media, and in certain trades national competitions started. Such competitions included the Kis Jankó Bori Embroidery

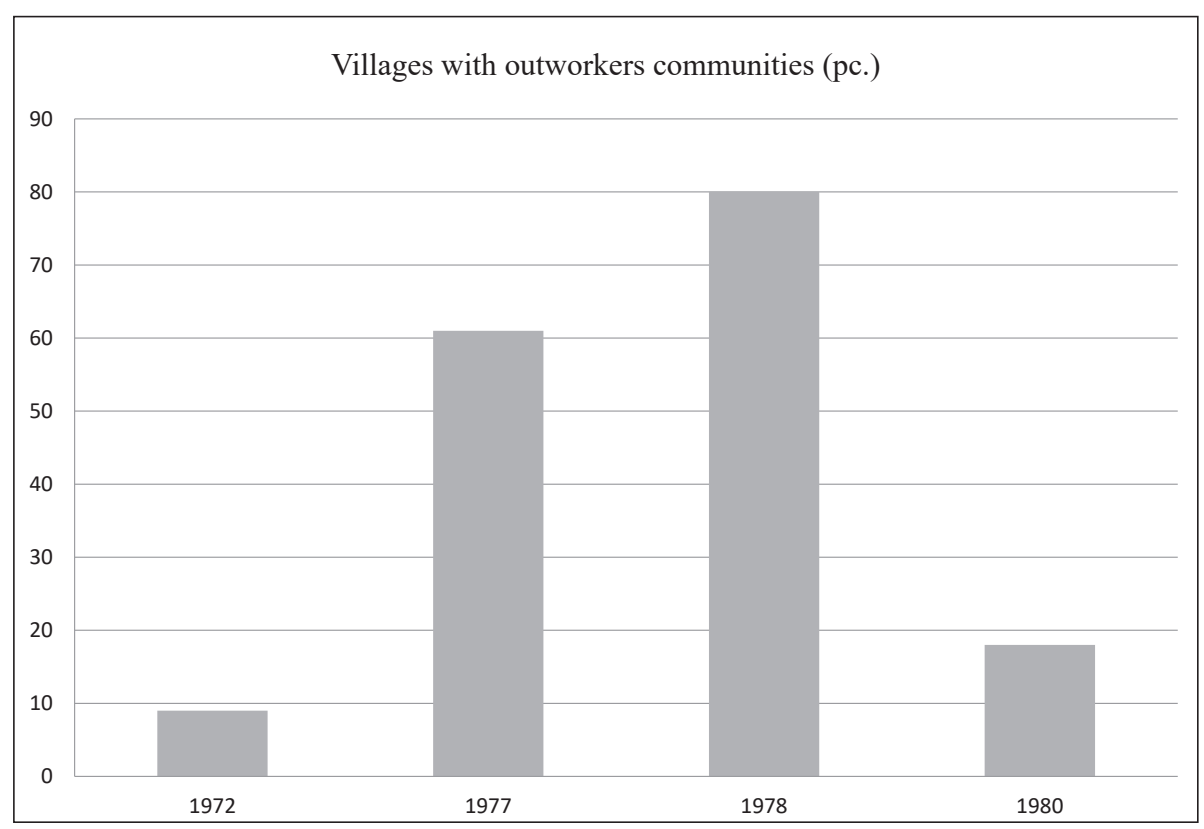

Figure 5. Villages with outworkers communities working for the Sárköz-region Folk Arts and Cottage Industry Co-operative with the union of Decs, Öcsény, Pilis and Báta. Source of figures: FLÓRIÁN 1990:233. 


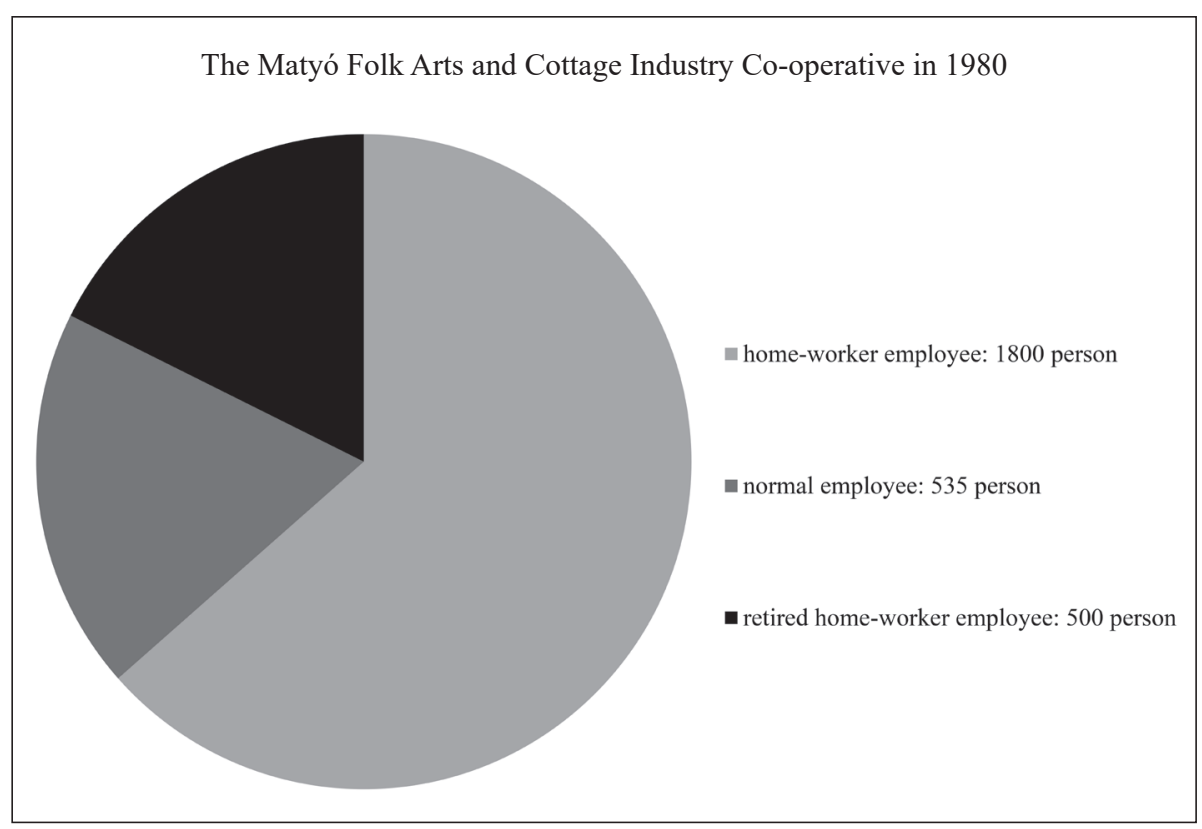

Figure 6. Distribution of employees in the Matyó Folk Arts and Cottage Industry Co-operative seated in Mezökövesd. Source of figures: FüGEDI 1997:69.

Competition in Mezőkövesd from 1963, Gerencsér Sebestyén Potter Competition in Siklós from 1966 (later on the National Potter Competition), Kapoli Antal Senior Wood Carver Competition from 1967 in Balatonlelle (and then in Budapest) the National Wood Carver Competition, from 1967 in Szekszárd (and Heves) the National Handweaver Competition, and from 1982 in Kecskemét (and Budapest) the National Handicrafts Competition (VARGa 2006:198). The National Folk Arts Exhibition (now: 'Living Folk Art' - National Folk Arts Exhibition) was organized in every three years, later on in every five years from 1973 on, where basically individual artists, the nomadic generation and the subject interest group movement were represented. Every now and then a talented co-operative artist appeared with his or her own works, pointing out eventually the great differences between co-operative employees in terms of creativity, technical skills, or the lack of them, for that matter (PUSKÁSNÉ OLÁH 1992).

Production value of the cottage industry co-operatives with applied folk art profile has approached HUF 1 billion by 1975. Promising financial results of the 1970s kept on increasing constantly up to 1980 . In the year of 1980 production value created by the folk art and cottage industry accounted for HUF 5.4 billion, HUF 600 million of which was the proceeds from the sale of juried applied folk art products. The co-operatives employed 56,000 workers. From 1981 on production costs gradually increased because of the changing market conditions. Export to Ruble relation destinations increased by $2 \%$ but was dropped by $10 \%$ to destinations with non-ruble accounting. Domestic sales figures started to plummet gradually on a year to year basis in spite of exemption from the $23 \%$ of value added taxes. Profitability of the co-operatives in 1980 was still at $12.2 \%$, dropping to $8.7 \%$ by 1983 . The co-operatives had to part with outworkers 


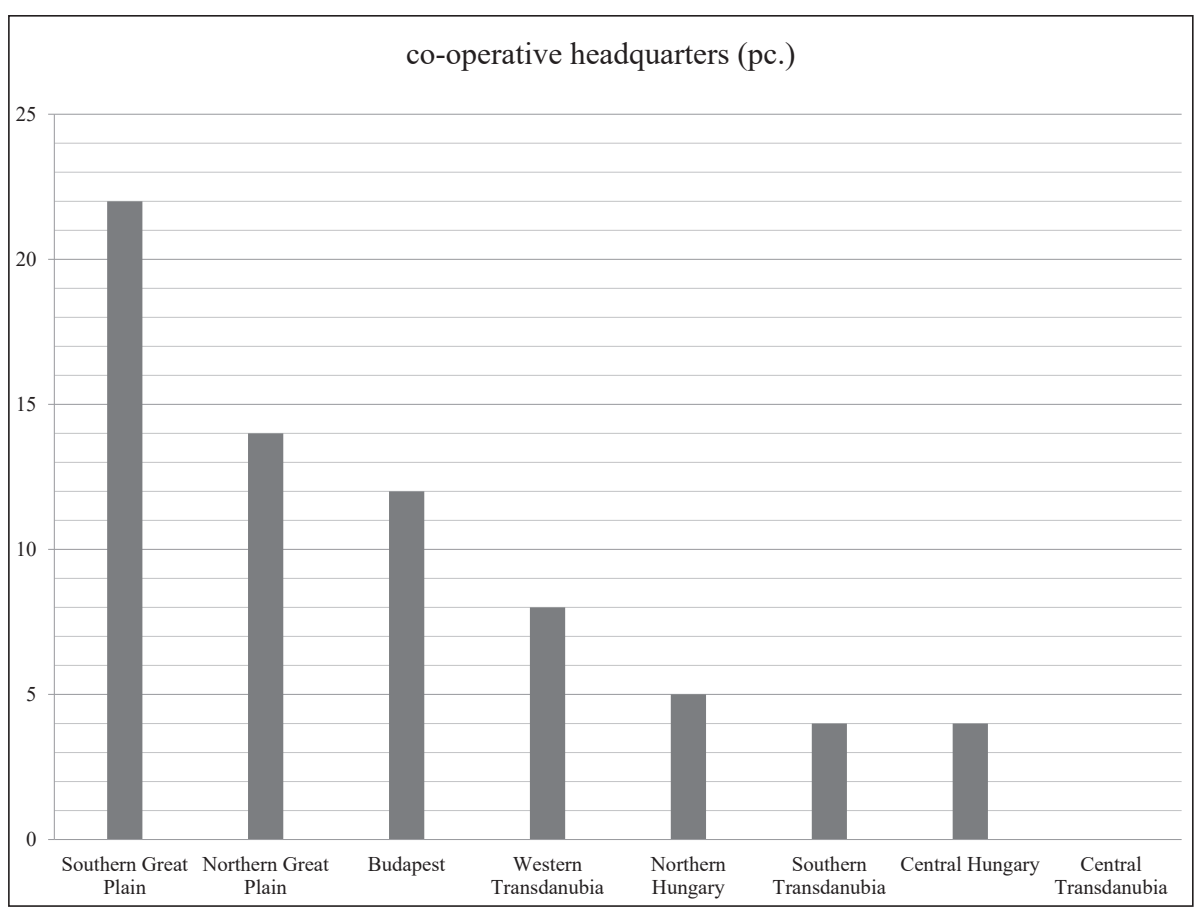

Figure 7. Regional distribution of co-operatives according to their headquarters, 1980. Source of figures: NAGY 1980.

who did not have any base wages and a number of founding members, mainly with women employed part time in the co-op, besides tending their ageing dependants or children. Seventy applied folk art and cottage industry co-operatives operated in 1982, 28 of which dealing specifically with the production of applied folk art products. In this single year, their turnover was worth HUF 3.5 billion, HUF 600 million of which was the proceeds from the sale of juried applied folk art products. Two thirds of these products were sold on export markets in the West (NAGY 1983: 16, 26; BÁDER 1985:88; LENDVAI 1985:79-86).

With reference to declining profitability the decision was made at the end of $1980 \mathrm{~s}$ about the wrap up of the HISZÖV, but member co-operatives were not liquidated at that time. (Fig. 7) The decision was promulgated by the Decree of the Ministerial Council published on 16 January 1982, and at the same time individual co-operatives were annexed to regional co-operatives. In fact, the heyday of the co-operative system has drawn to an end, in spite of certain co-operatives still functioning on for 1 or 2 decades. Neither co-operatives, nor the central bodies and organizations trying to unite them (Society of Applied Folk Art and Cottage Industry Co-operative, Association of Applied Folk Art Co-operatives, National Cottage Industry Alliance) proved to be unsustainable after the turn of the millennium (NAGY 1980:26-27; VARGA 2006:205). The very last spectacular event of the age of the co-operatives, revoking the glamour of the past decades was the opening of the Collection of Applied Folk Art in Kecskemét in December 1984. Artifacts of the Budapest NIT collection were lodged at the exhibition site as deposits, 
and an overwhelming majority of the overhead costs (90 per cent initially, then the entire amount) was covered by the city of Kecskemét (KRISKóNÉ DÁvID 1998:31).

Headcount of the professional supervisory body of the co-operatives, the NIT was increased from 14 to 25 at the time the HISZÖV was liquidated and its role was theoretically broadened with the full scale jury obligation of any products in circulation on the domestic market, but this qualification system was applied more and more in principle only and with the political transition its significance was lost almost entirely. The Applied Folk Art Council also had to part with its independence and was engulfed by the Hungarian Education Institute, then kept on functioning as the Applied Folk Art Department of the House of Traditions from 2004 on. The department was divided up in two in 2015, the Applied Folk Arts Department dealing with jury activities, the Museum of Hungarian Applied Folk Art with the preservation of the NIT art collection, and presenting, documenting contemporary applied folk art. Employees working in the co-operatives as outworkers earlier on have been completely displaced from the sector with the loss of their jobs almost entirely. More gifted artisans started their own businesses but they got into a more helpless situation in terms of their livelihood. In spite of all good intentions, their institution, reduced to a certification body, the Applied Folk Art Department of the Hungarian Heritage House, or their umbrella organization, the Association of Hungarian Folk Artists (NESZ) have are not in the position to provide safe and permanent living as employers, like a former cottage industry co-operative used to do. ${ }^{21}$

\section{PERSONAL CULT}

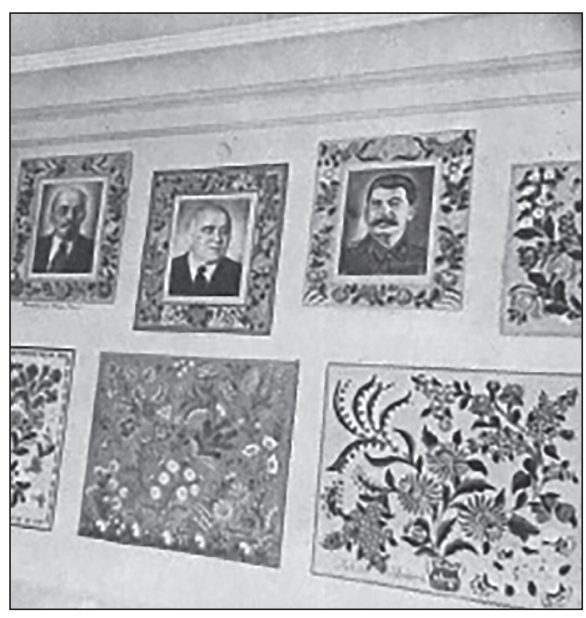

Figure I.1. Painting competition in Kalocsa. (WeINER 1952, illustration plate No. XXXVII)

$\overline{21}$ On the perspectives of folk art see: BALOGH 2010. 
Cottage Industry Co-Operatives with Applied Folk Art Profile in Hungary... 205

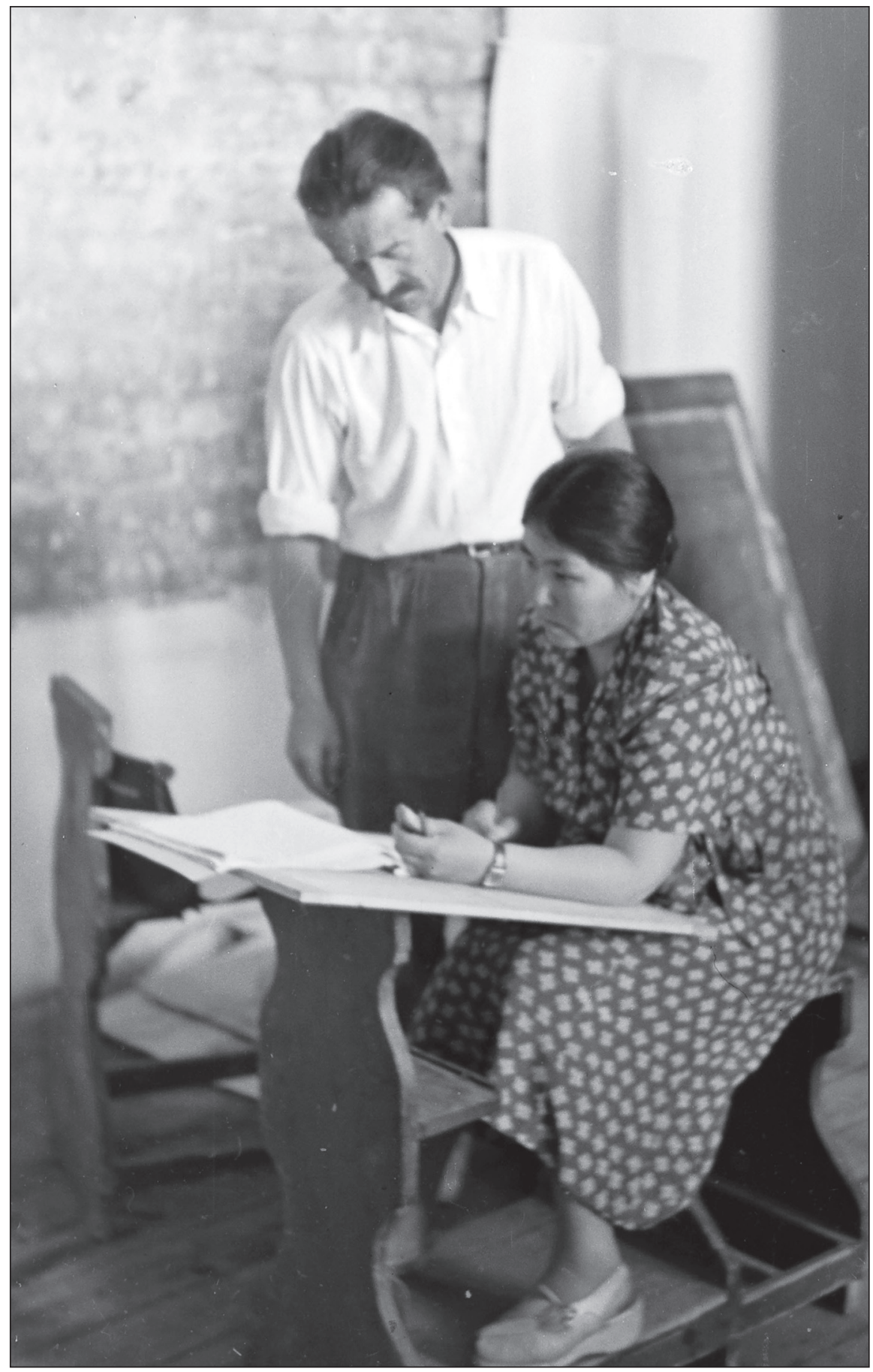

Figure I.2. Mrs. Rákosi and Miklós Borsos. (Fortepan/ Márton Ernő Kovács) (accessed January 11, 2020) 


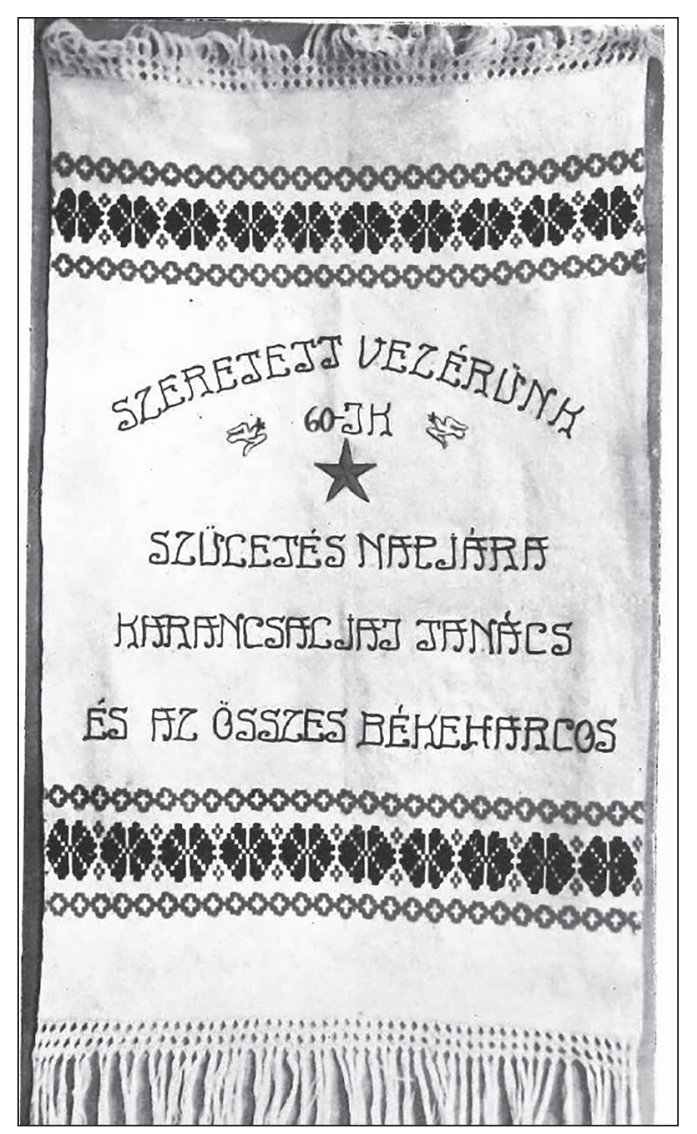

Figure I.3. For the $60^{\text {th }}$ birthday of our much beloved leader from the Karancsalja Village Council and all the peace warriors. Decorative towel, a gift from the Karancsalja Village Council to the $60^{\text {th }}$ birthday of Mátyás Rákosi. (BоKOR 1952:25)

Figure I.4. Tea set painted by Mrs. Rákosi at the III. Hungarian Folk Arts and Applied Arts Exhibition, in the Museum of Applied Arts. (Domanovszky 1955)

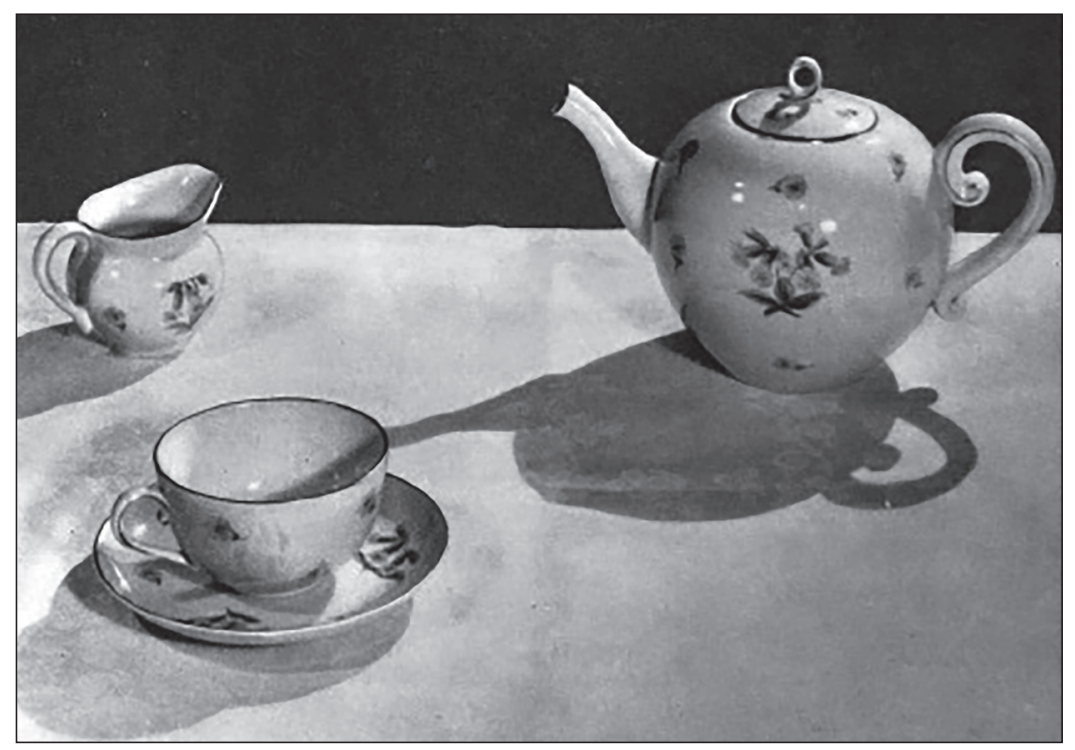




\section{FESTIVE OCCASIONS}

A characteristic feature of the period was that creators - mainly women - appeared on official festivities in folk dresses, costumes instead of casual dresses.

From the collection of Museum of Hungarian Applied Folk Art, Hungarian Heritage House

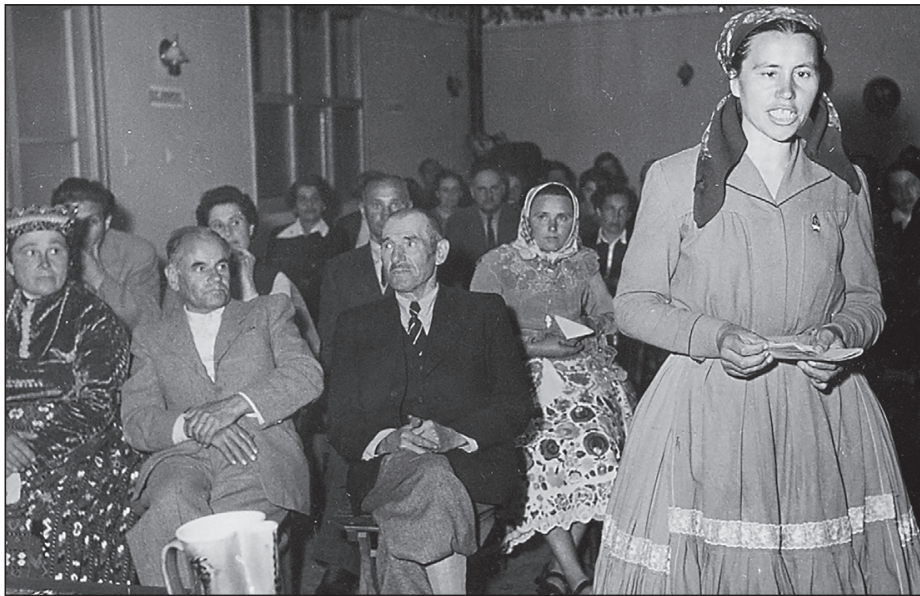

Figure II.1. Festive report at Kalocsa in the middle of the 1950s. Mrs. Máté Maticsányecz, Sándor Kántor, unknown person, Mrs. István Bali standing on the right hand edge of the picture

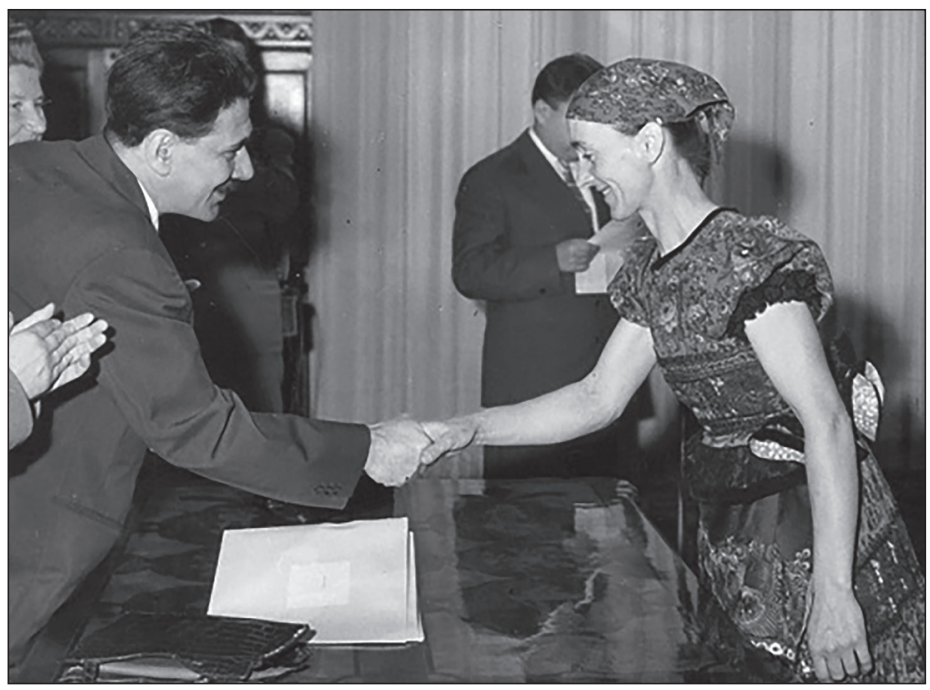

Figure II.2. Mrs. István Káló and György Aczél (presumably on the occasion of award ceremony of the Master of Folk Art, 1959) 
III. SOCIALIST REALISM IN DECORATIVE FOLK ART OBJECTS EXHIBITED ON REPRESENTATIVE OCCASIONS

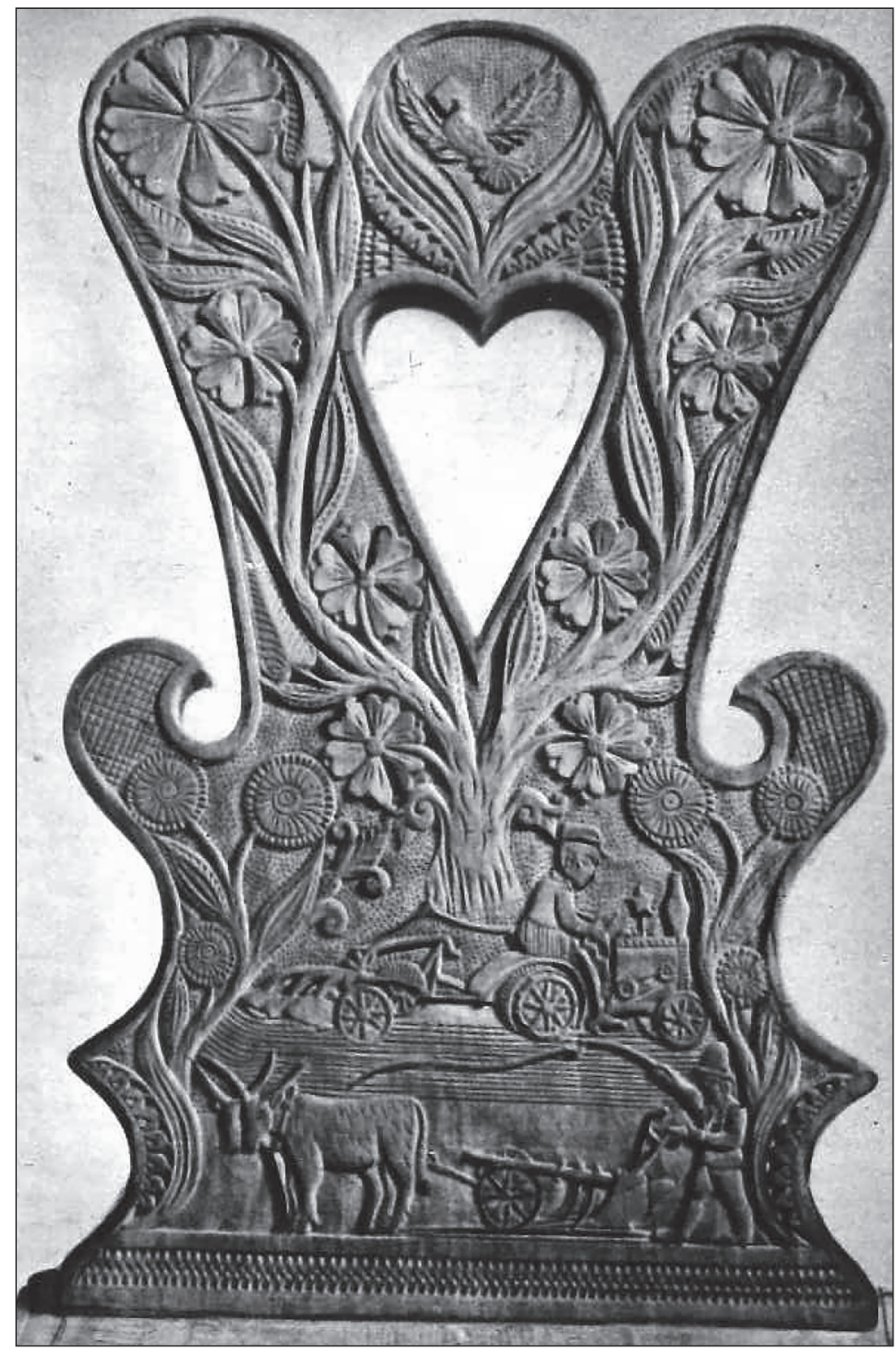

Figure III.1. István Kálmán: Back support of a chair with dove of peace, and the allegory of agricultural mechanization at the first Folk Arts and Industrial Arts Exhibition. (Schubert - Balassa (eds.) 1953) 


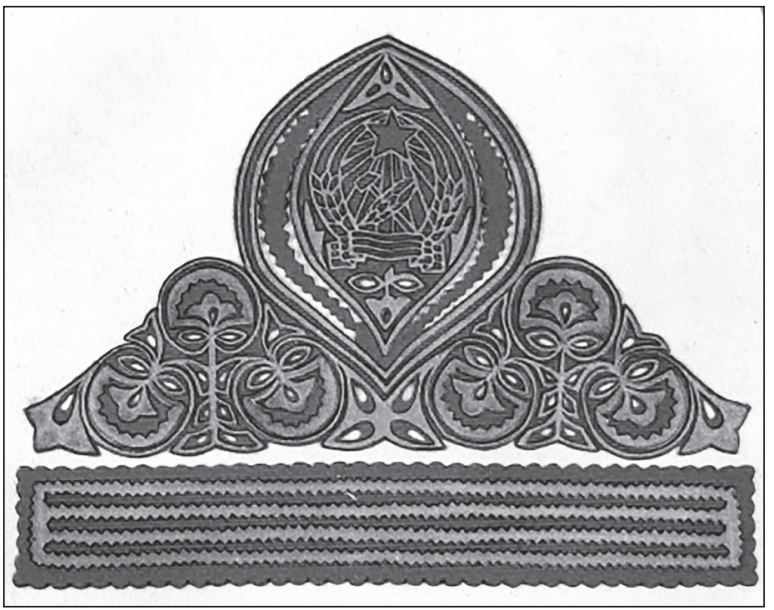

Figure III.2. Felt appliqué picture album with 'Rákosi-coat of arms', a gift from the Hajdú-Bihar County Council to the 60th birthday of Mátyás Rákosi. (BoKor 1952)

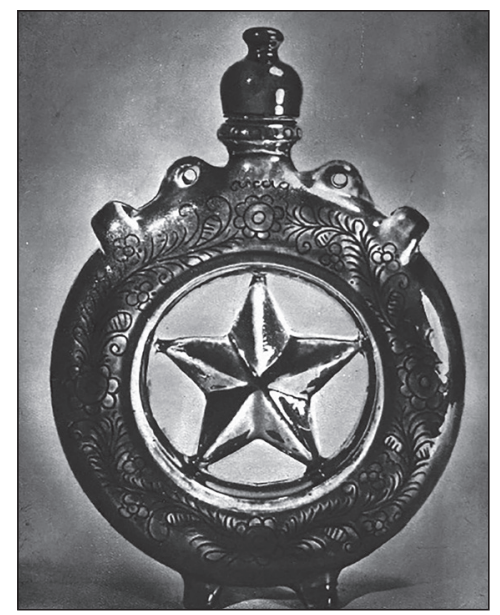

Figure III.3. Sándor Kántor: pretzel flask with red / Communist star on the first Folk Arts and Industrial Arts Exhibition. (SCHUBERT - BALASSA (eds.) 1953)

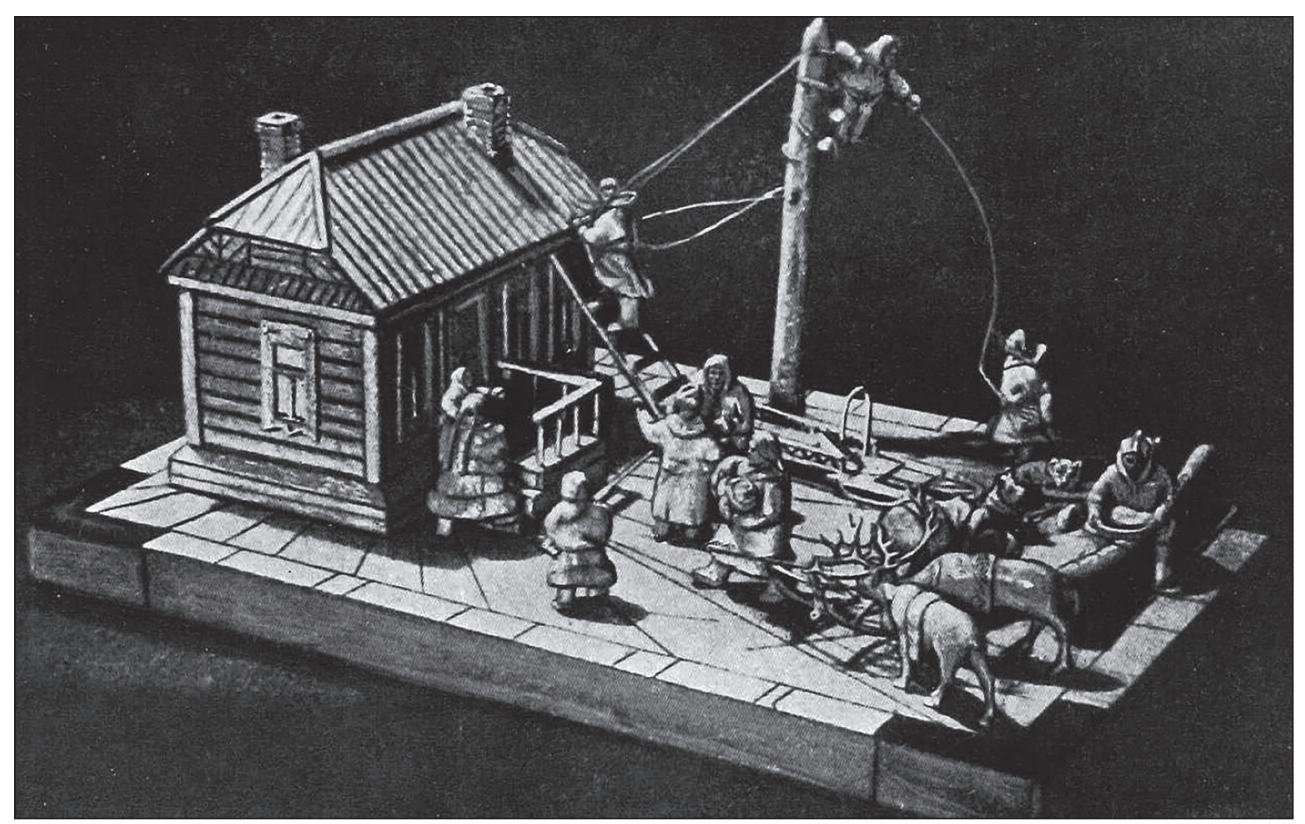

Figure III.4. Sinicki: Installation of electricity on the Tundra, mammoth bone carving. (WeINER 1952. Illustration plate No. XVIII) 


\section{GENRE PHOTOGRAPHS OF MASTERS OF FOLK ART}

Creators usually look back at us from rigidly composed pictures, their working environment, folk costumes are not fit for the occasion.

From the collection of Museum of Hungarian Applied Folk Art, Hungarian Heritage House

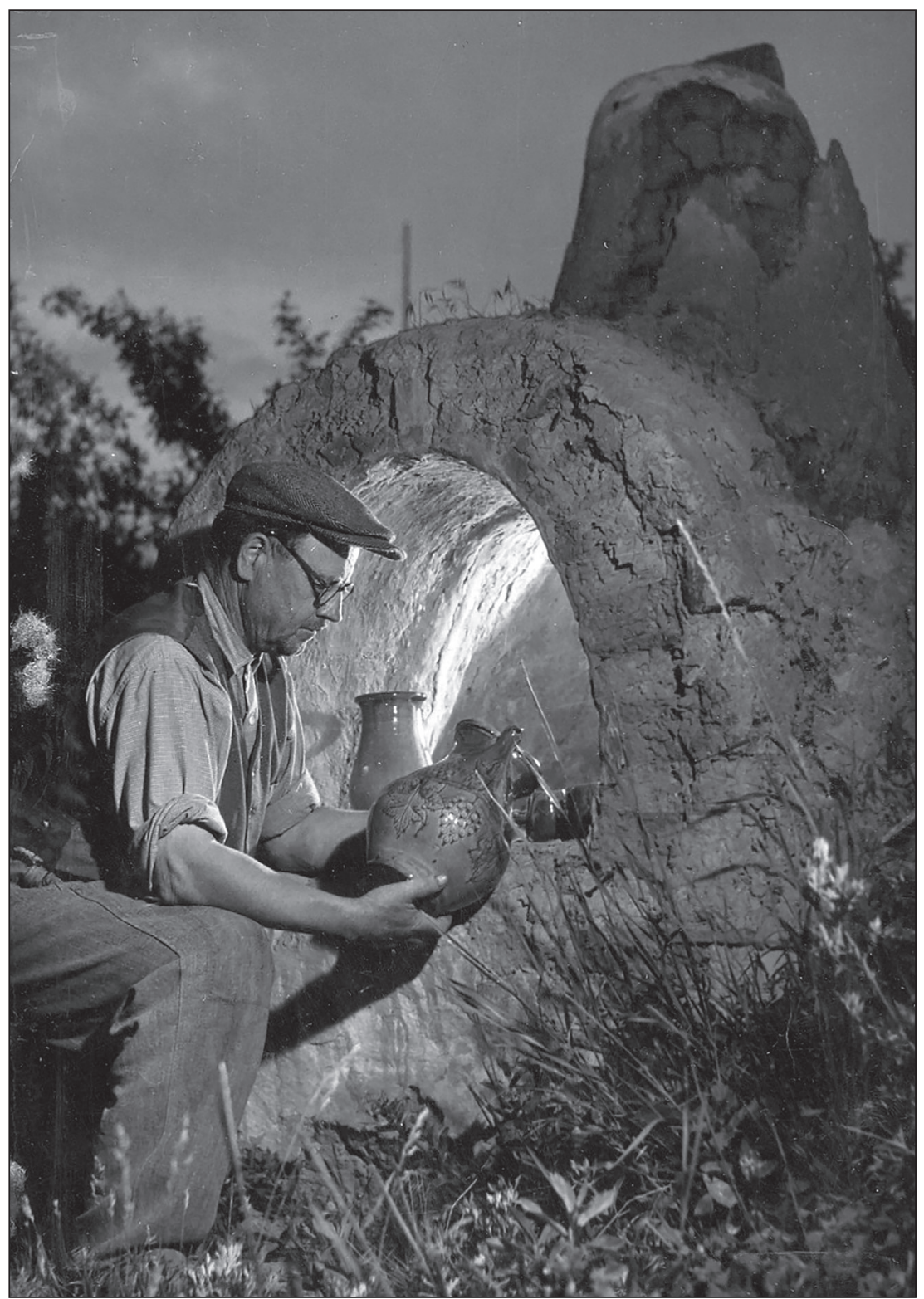

Figure IV.1. János Csizmadia, potter 
Cottage Industry Co-Operatives with Applied Folk Art Profile in Hungary... 211

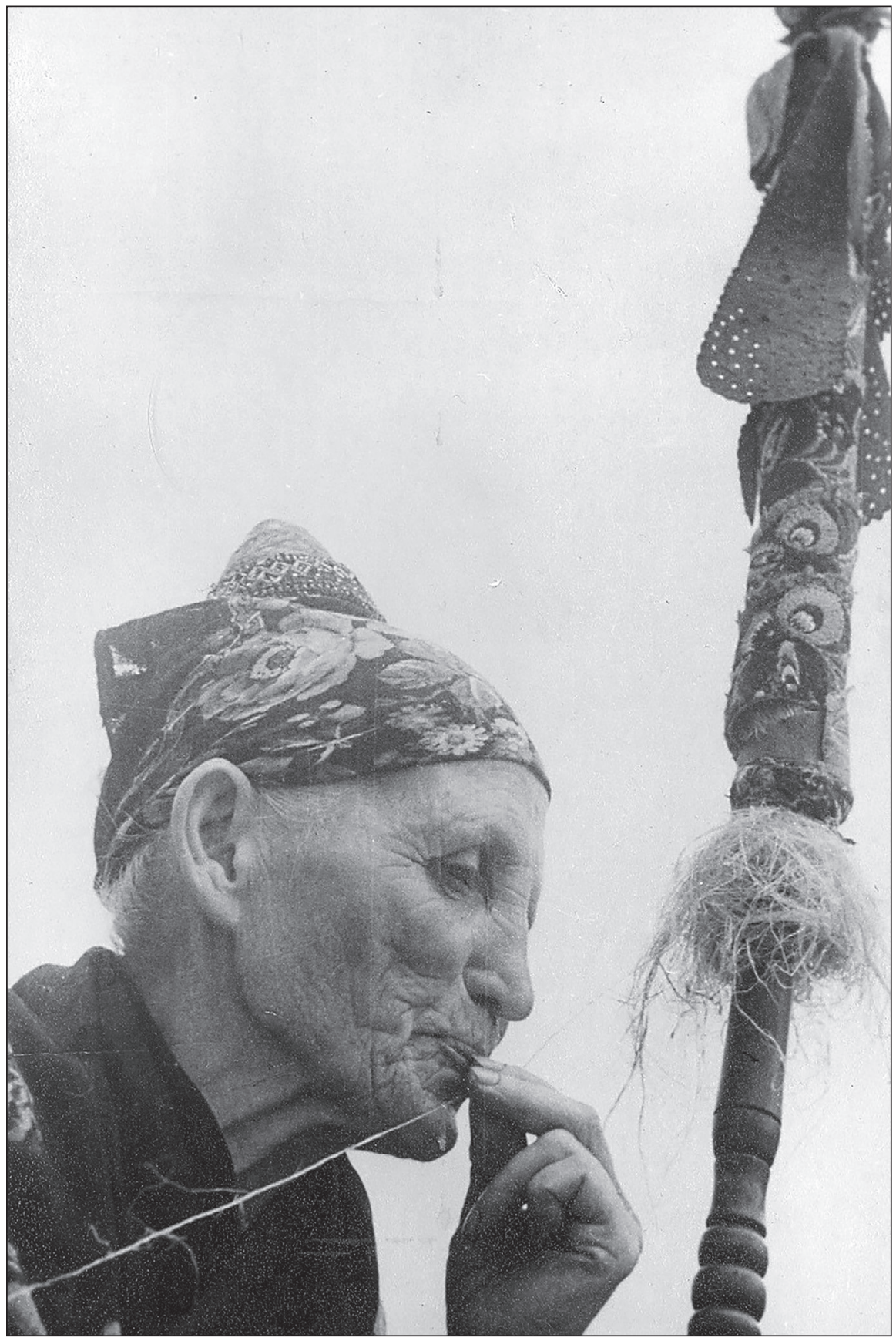

Figure IV.2. Bori Kis Jankó (Mrs. Márton Gáspár), embroideress 


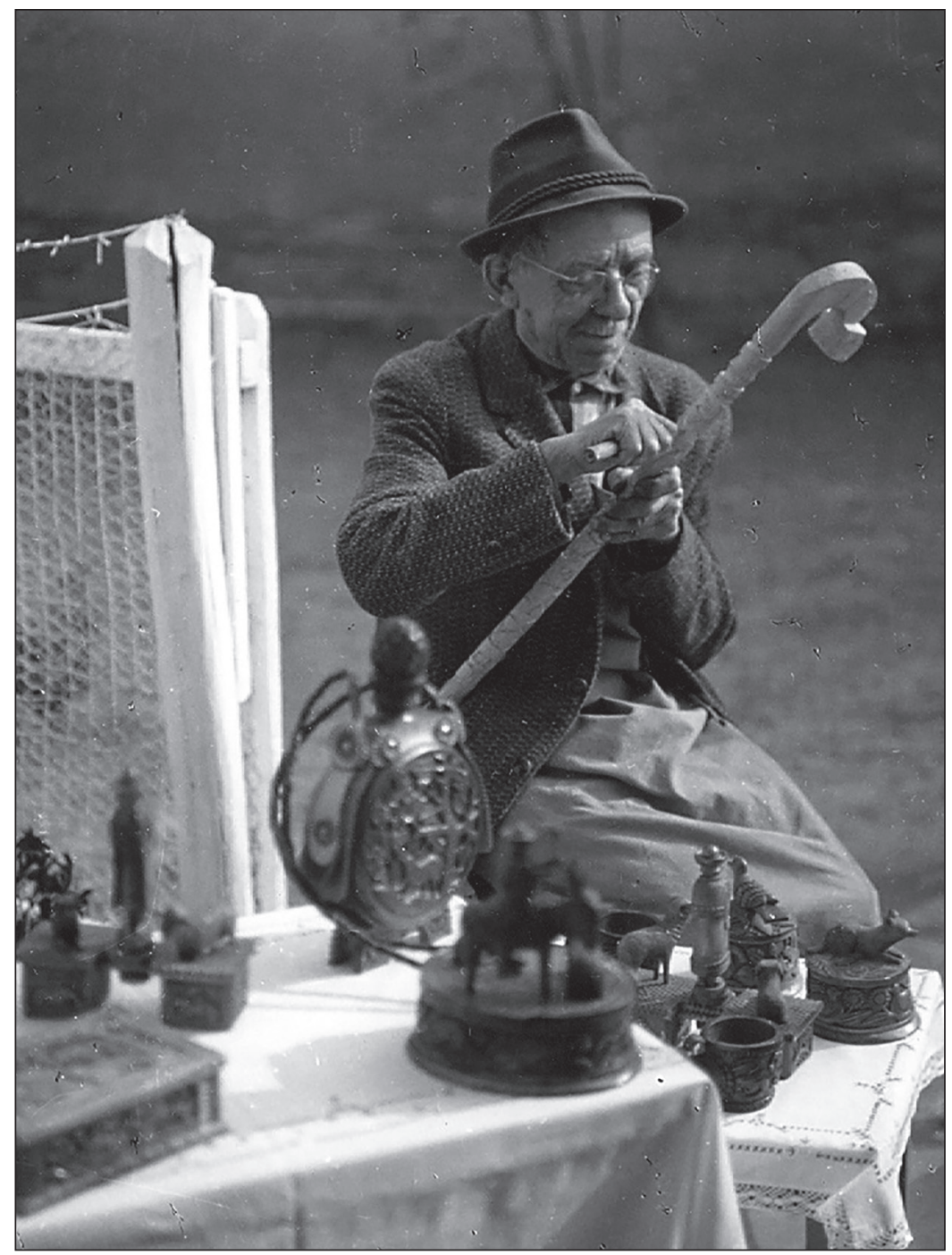

Figure IV.3. Kálmán Breglovics, wood-carver 


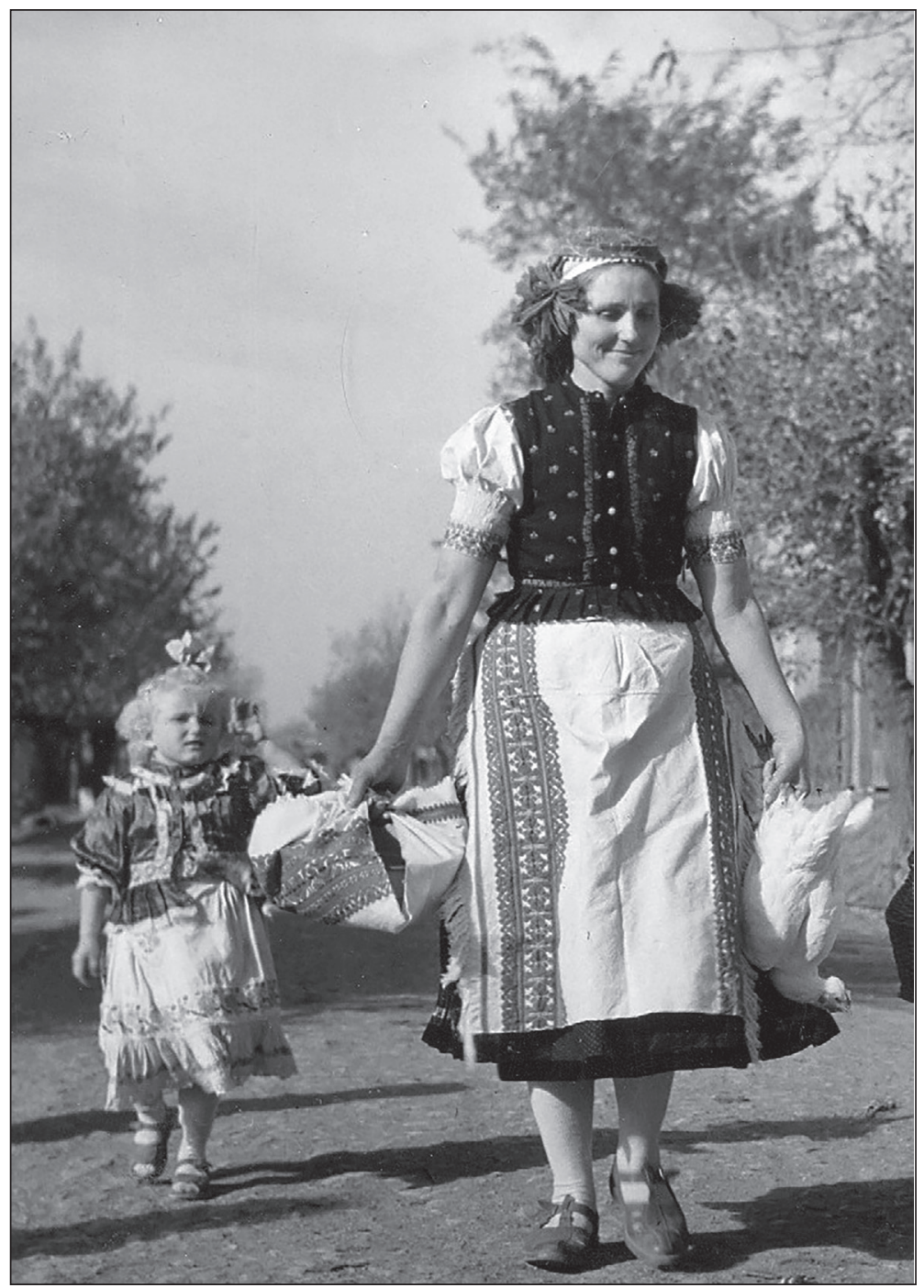

Figure IV.4. Mrs. József Lévai, embroideress 


\section{SÁRKÖZI COTTAGE INDUSTRY CO-OPERATIVE, DECS}

Modern articles of clothing with traditional patterns from the 1970s.

From the collection of the Museum of Hungarian Applied Folk Art, Hungarian Heritage House

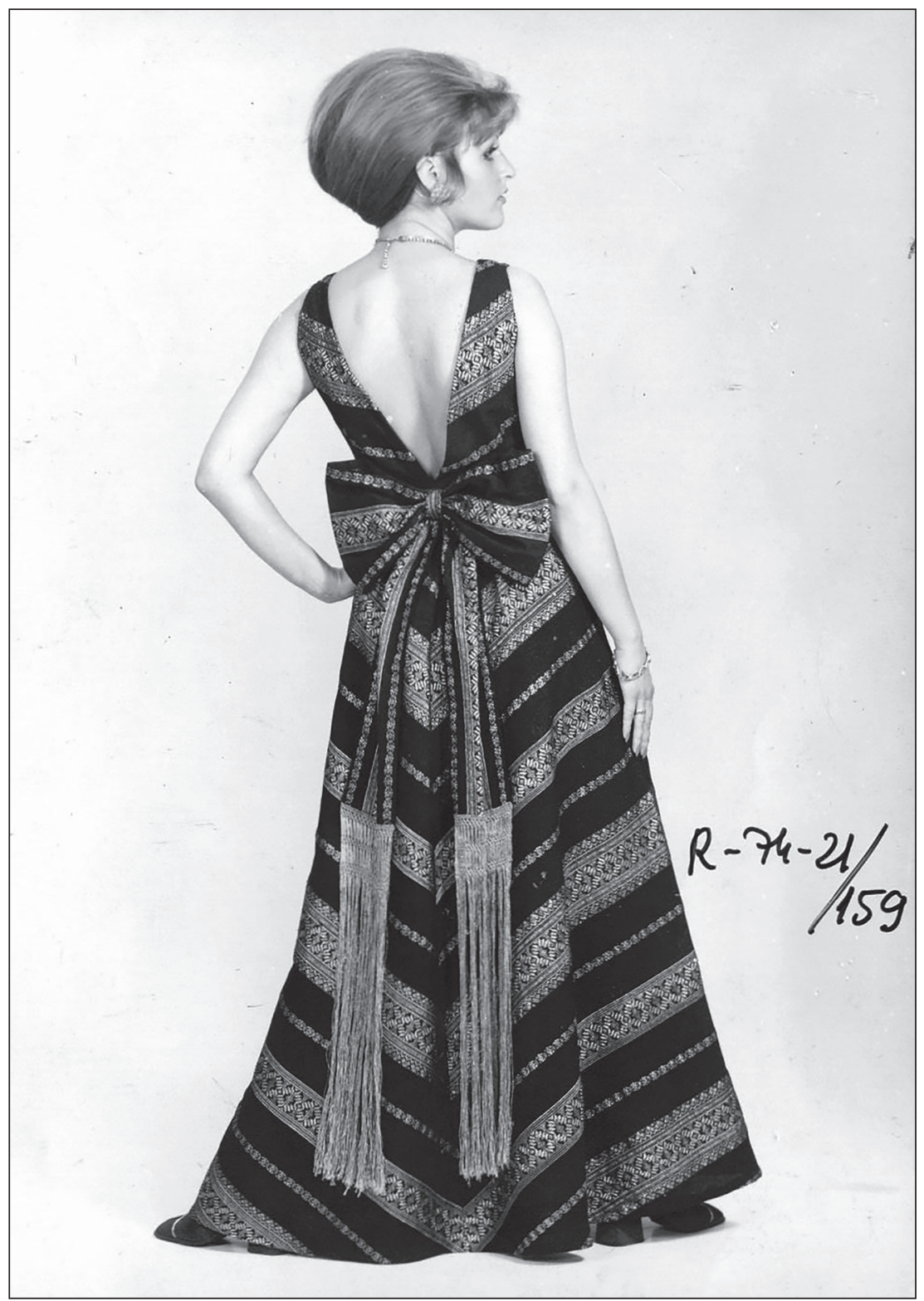

Figure V.1. Sárközi hand-woven cloth with bow from a full evening dress (R-74-21/159) 
Cottage Industry Co-Operatives with Applied Folk Art Profile in Hungary... 215

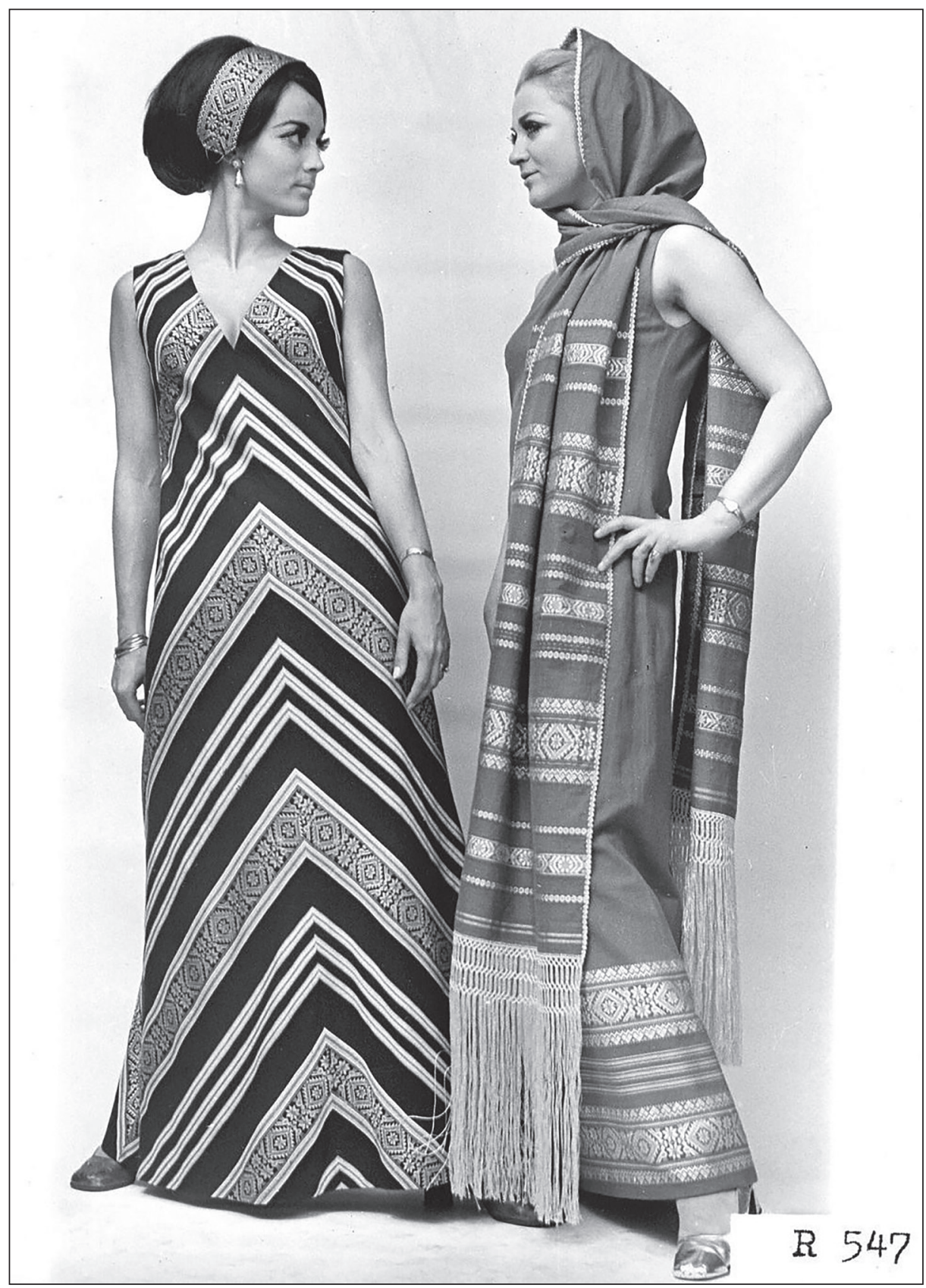

Figure V.2. Sárközi homemade hand-woven fabric named Zsuzsa with half-heddles full evening dress patterns (R547) 


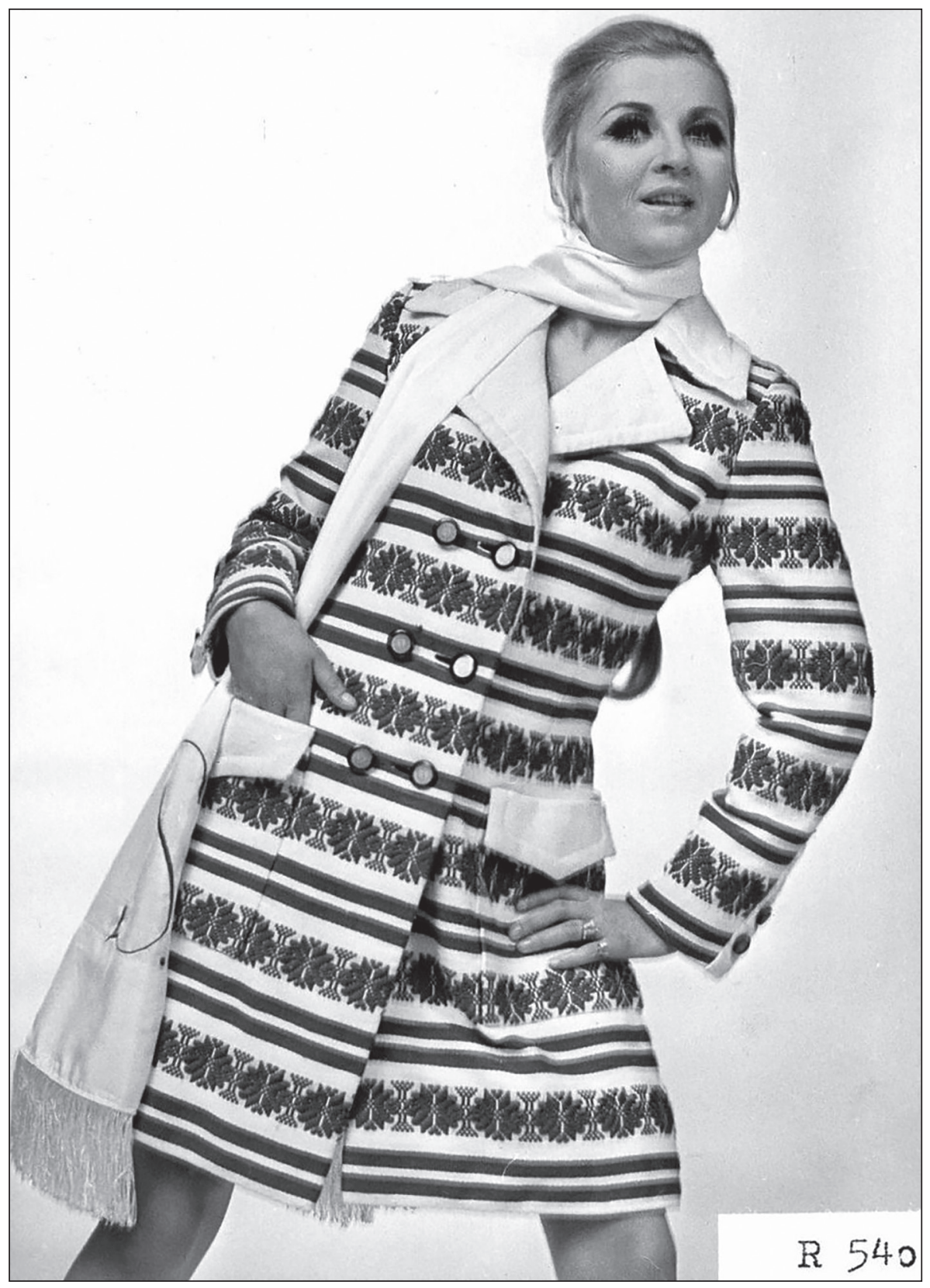

Figure V.3. Ildikó hand-woven coat with half-heddles design (R540) 


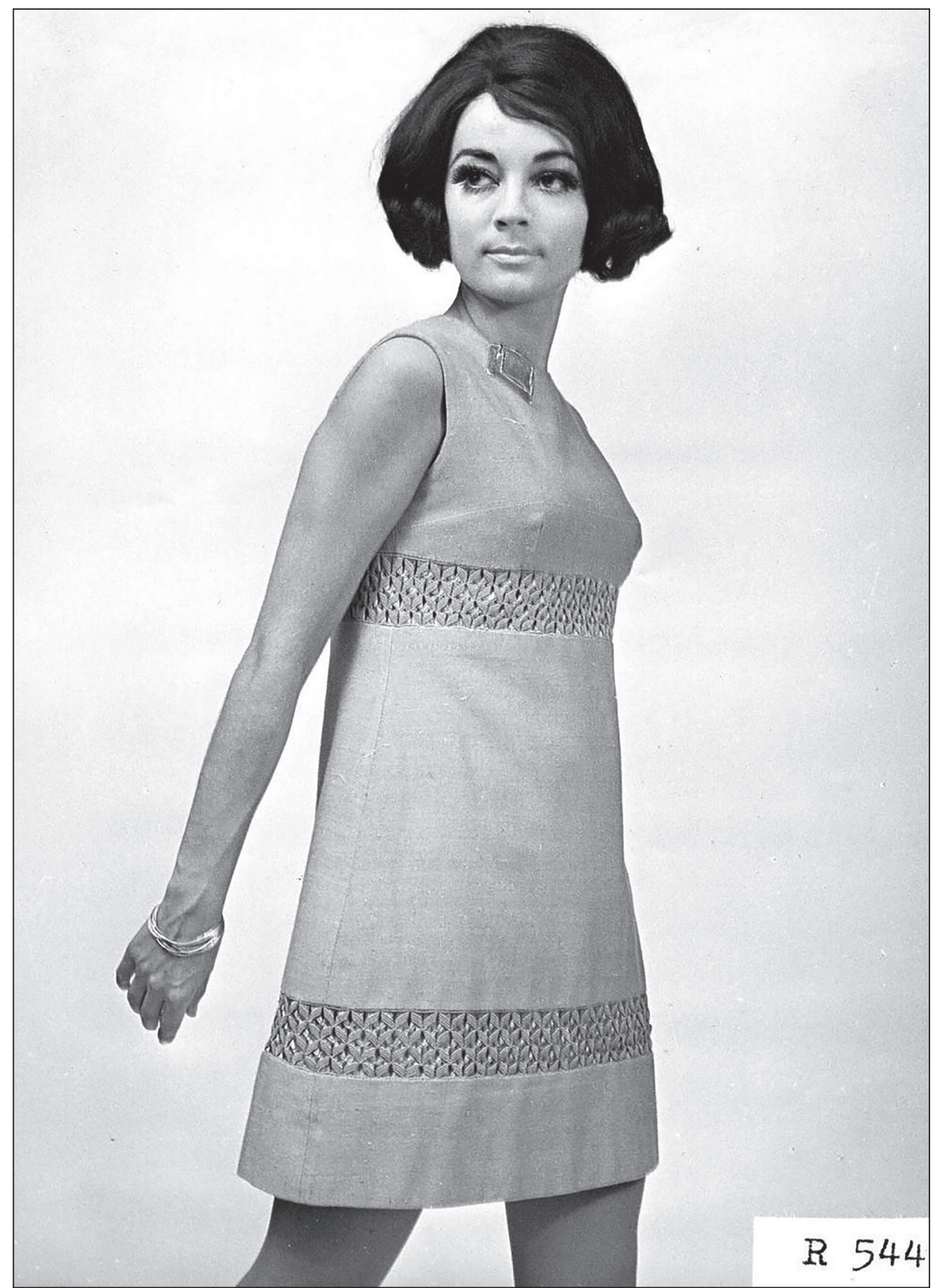

Figure V.4. Judith hand-woven dress with fringe tie (R554) 


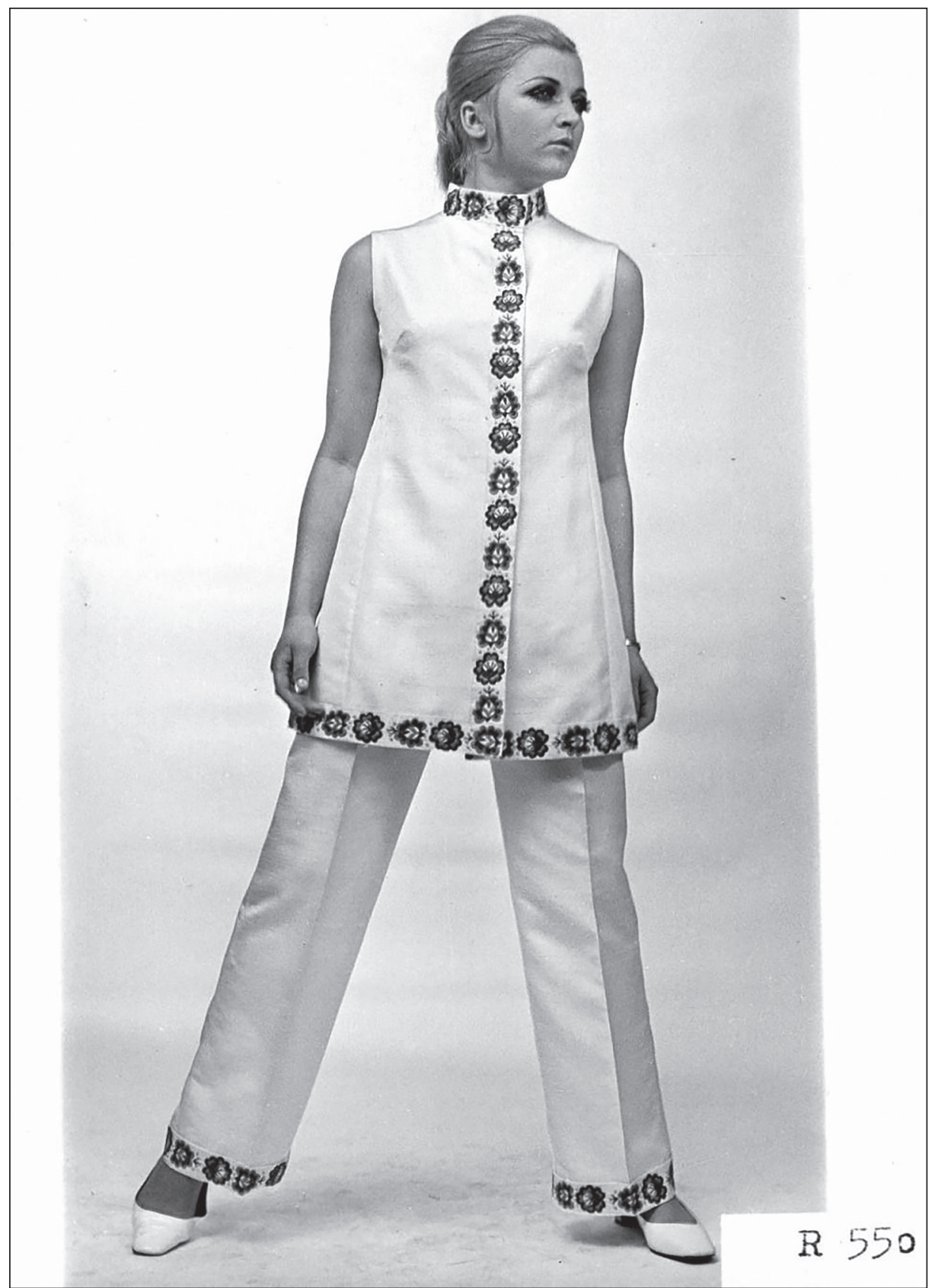

Figure V.5. Sanny mini dress and trousers using raw shantung and corded cotton (R550) 


\section{REFERENCES CITED}

Ament-Kovícs, Bence

2017 Boross Marietta köszöntése [Greetings to Marietta Boross]. Néprajzi Hírek XLVI(3): 69-71.

2019a Háziipari és népi iparmüvészeti szövetkezetek a második világháború utáni Magyarországon [Cottage Industry and Applied Folk Art Profile Co-operatives in Hungary after World War II]. Honismeret XLVII(3):17-23.

2019b Szövetkezeti örökség [Heritage of the Co-operatives]. Ethnographia CXXX(4):684-689.

BÁDER, Miklósné

1985 Gazdaságiéstársadalmiproblémákaháziipariésnépművészetiszövetkezeteknél [Economic and Social Problems at the Cottage Industry and Applied Folk Art Co-operatives]. In BALASSA, M. Iván (ed.): Népi iparmüvészetünk idöszerü kérdései II, 87-91. Budapest-Pécs: Népi Iparmüvészeti Tanács.

2004 Alkotó közösségek szerepe a hagyományőrzésben [The Role of Creative Communities in the Preservation of Traditions]. In Petercsák, Tivadar (ed.) Agria XLII, 467-476. Eger: Dobó István Vármúzeum.

BALASSA, Iván

1980 Népmúvészet, népi iparmüvészet [Folk Art, Applied Folk Art]. In VARGA, Marianna - Szabó, Rózsa (eds.) Népi iparmüvészetünk idöszerü kérdései. I, 9-26. Budapest: Népi Iparművészeti Tanács.

BALOGH, Balázs

2003 Boundaries of prestige groups in a local peasant community - The example of village Táp, Transdanubia, Hungary In: KorHONEN, Teppo - RuOTSALA, Helena - Uusitalo, Eeva (eds.) Making and Breaking of Borders. Ethnological Interpretations, Presentations, Representations, 111-118. Helsinki: Finnish Literature Society.

2010 "Folk Art" in Hungary Today - Question Marks, Challenges and Perspectives. In HoppáL, Mihály (ed.) Sustainable Heritage, 125-129. Budapest: European Folklore Institute.

BAlogh, Balázs - FülemiLE, Ágnes

2008 Cultural Alternatives, Youth and Grassroots Resistance in Socialist Hungary The Folk Dance and Music Revival. Hungarian Studies 22:43-62.

BÁNSZKY, Pál

2004 A hagyomány és korszerüség viszonyának alakulása az utóbbi 50 év tárgyi népmüvészetében [Trends in the Relations between Tradition and Modernity in the Folk Art of the Last 50 Years]. In Petercsák, Tivadar (ed.) Agria XLII, 373-377. Eger: Dobó István Vármúzeum.

BÁRÁNY, Balázs

2017 A jó, a rossz és a szocdem? Marosán György, Nagy Imre és Kádár János pályafutásának ingamozgásai [The Good, the Bad, and the Social Democrat? Pendulum Movements in the Careers of György Marosán, Imre Nagy and János Kádár]. In FáBIÁN, Máté - Romsics, Ignác (eds.) RMJ60. Tanulmányok a hatvanéves Rainer M. János tiszteletére, 17-39. Eger: Líceum Kiadó. 
BECK, Zoltán

1967 Orosháza és Környéke Háziipari Termelöszövetkezet [Orosháza and Environs Cottage Industry Agricultural Co-operative]. Orosháza.

BENCSIK, JÁNOS

1997 Háziipar [Cottage Industry]. In FüGEDI, Márta (ed.) Borsod-Abaúj-Zemplén megye népmüvészete, 55-76. Miskolc: Herman Ottó Múzeum.

BESZPRÉMY, Katalin

2004 Iskolai és iskolán kívüli képzések a népi kézmüvesség területén [In and Offschool Training Programmes in the Field of Folk Handicrafts]. In PETERCsák, Tivadar (ed.) Agria XLII, 461-465. Eger: Dobó István Vármúzeum.

BoDrogi, Tibor

1979 Magasabb hatványon [At a Higher Power]. Kritika 8(3):8-9.

BoKor, Miklós

1952 Népünk szeretete. Népmüvészeink ajándékai Rákosi Mátyás 60 éves születésnapjára [The love of our people. Gifts to the $60^{\text {th }}$ Birthday of Mátyás Rákosi]. Budapest: Képzőmüvészeti Alap.

BRown, Archie

1979 Eastern Europe: 1968, 1978, 1998. Daedalus 108(1):151-174.

CSEH, Fruzsina

2014 A kerékgyártó mesterség múltja Magyarországon [History of the Wheelwright Trade in Hungary]. (Életmód és Tradíció 13.) Budapest: MTA Bölcsészettudományi Kutatóközpont.

2020 Folk Artisans and Dissidence in the Nomadic Generation of the 1970s and 1980s. Acta Ethnographica Hungarica 65(1):227-253.

DomanovszKy, György

1955 III. Magyar Iparmüvészeti és Népmüvészeti Kiállitás [Third Hungarian Applied Art and Folk Arts Exhibition]. (Budapest): Atheneum.

1956 Népmüvészetünk időszerü kérdései [Current Issues in our Folk Arts]. Szabad Müvészet X(1-2):17-23.

1973 (Preface). In Varga Marianna (ed.) Népi Iparmüvészet 1953-1973, 1-4. Budapest: Magyar Nemzeti Galéria - Népi Iparmúvészeti Tanács.

1983 Mai magyar népi iparmüvészet [Contemporary Hungarian Applied Folk Art]. Budapest: Képzőmüvészeti Kiadó.

FEJös, Zoltán

2012 „Rákosi elvtárs élete” - egy hatvan évvel ezelőtti sztárkiállítás rétegei [“The Life of Comrade Rákosi” - layers of a Star Exhibition Held Sixty Years Ago]. Ethnographia CXXIII(1):1-47.

FÉL, Edit

1975 Népi hímzés [Folk Embroidery]. In KuczKa Péter (ed.) Népi iparmüvészet 1945-1975, 6-9. Budapest: Hungexpo.

FÉL, Edit - HoFER, Tamás

1969 Proper Peasants. Traditional Life in a Hungarian Village. Chicago: Aldine Publishing.

FLóRIÁN, Mária

1990 A ,sárközi szőttes” története [History of the 'Sárközi Handwoven Fabric']. Ethnographia CI(2):194-256. 
1992 Beszélhetünk-e 1992-ben Budapesten „élơ” népmüvészetről? [Can we Talk about Living Folk Art in 1992 in Budapest?]. In BorbéLY, Jolán (ed.) Élő népmüvészet. X. Országos Népmüvészeti Kiállitás katalógusa, 4-5. Budapest: Néprajzi Múzeum.

2009 Öltözködés [Dressing]. In PaLÁDI-Kovécs, Attila (ed. in chief) Magyar Néprajz I.2. Táj, nép, történelem 586-594.Budapest: Akadémiai Kiadó.

FöGLEIN, Gizella

2001 Államforma és államföi jogkör Magyarországon 1944-1949 [Form of Government and the Sphere of Authority of the Head of State 1944-1949]. Budapest: Osiris Kiadó.

FüGEDI, Márta

1997 Mitosz és valóság: A matyó népmüvészet [Myth and Reality: Matyó Folk Art]. Officina Musei 6. Miskolc: Herman Ottó Múzeum.

FüLEMILE, Ágnes

2018 Folk Art Heritage and Traditions in Hungary. In GöTz, Eszter (ed.) Kéz/Mü/ Remek. Nemzeti Szalon 2018. Népmüvészet. Hand/Craft/Art. National Salon 2018. Folk Art, 62-77. Budapest: Mücsarnok Nonprofit Kft.

FÜVESSY, Anikó

2004 Átmentett hagyomány a Közép-Tiszavidék népi iparművészetében [Surviving Tradition in the Applied Folk Art of the Middle-Tisza Region]. In Petercsák, Tivadar (ed.) Agria XLII, 407-413. Eger: Dobó István Vármúzeum.

FüZES, Endre

2012 A népi iparmủvészet felülvizsgálata 1999-2000 [Reviewing Applied Folk Art), 1999-2000]. In BerECZKI, lbolva - Cseri, Miklós - FüZES, Endre (eds.) A szántalpas hombártól a tájházig, 411-418. Szentendre: Szabadtéri Néprajzi Múzeum.

GRÁFIK, Imre

2006 Kézmủves hagyomány és tárgykultúra [Tradition of Handicrafts and Object

Heller, Ágnes Culture]. Ethnographia CXVII(4):229-250.

2000 1968. In RÉvÉsz, Sándor (ed.) Beszélő évek. 1957-1968. A Kádár korszak története I, 558-566. Budapest: Beszélő Politikai Folyóirat.

Ifjúsági képzőművészeti...

1950 Ifjúsági képzömüvészeti és iparmüvészeti kiállitás [Fine Arts and Applied Arts Exhibition of the Youth] Nemzeti Szalon. (Budapest).

JuHÁsz, Katalin

2018 „Nomád nemzedék”: táncház- és népművészeti mozgalom - oral history archívumokban ["Nomadic Generation": Dance House Movement and Folk Art Movement in Oral History Archives]. In APOR, Péter - Bódi, Lóránt HoRváth, Sándor - HuHÁk, Heléna - SCHeIBNer, Tamás (eds.) Kulturális ellenállás a Kádár-korszakban: Gyüjtemények története, 273-294. Budapest: MTA BTK Történettudományi Intézet.

KAPITÁNY, Orsolya, L.

1998 Tamás László fazekas, a Népmüvészet Mestere [László Tamás Potter, Master of Folk Arts]. Népi Iparmüvészek Somogyban II. Kaposvár: Somogy Megyei Múzeumok Igazgatósága. 
KEREKES, Ibolya

2014 A tápai gyékényszövő háziipar a 20. században [Rushwork Pleating Industry in the $20^{\text {th }}$ Century in Tápa (Tápé')]. In BÁRKÁNYI, Ildikó - LaJkó, Orsolya, F. (eds.) A Móra Ferenc Múzeum Évkönyve Új folyam 1, 455-478. Szeged: Móra Ferenc Múzeum.

KóRó, Józsefné

1961 Tíz éves a matyó szövetkezet [Ten Years Old is the Matyó Co-operative]. In Molnár, László (ed.) Matyó Népmüvészeti és Háziipari Szövetkezet, 34-41. Mezőkövesd: Matyó Hisz.

KRESZ, Mária

1952 Népi díszítőművészetünk fejlődésének útjai [Development Paths of Decorative Folk Arts in Hungary]. Ethnographia LXIII(1-2):10-43.

KRISKÓNÉ DÁVID, Mária

1998 A népi iparmüvészet múzeuma Kecskeméten [The Collection of Applied Folk Art in Kecskemét]. Magyar Múzeumok 4(1):31-32.

LENDVAI, István

1985 Gazdaságunk és a népi iparmúvészet [Economy and Applied Folk Art]. In BALassa M., Iván (ed.) Népi iparmüvészetünk idöszerü kérdései II, 79-86. Budapest - Pécs: Népi Iparmúvészeti Tanács.

LENGYEL, Györgyi

1952 Hogyan készültek a népmüvészek Rákosi elvtárs születésnapjára [How Folk Artists got Prepared to the Birthday of Comrade Rákosi]. Szabad Müvészet VI(4):173-175.

1980 A népi iparmúvészet történetéből [From the History of Applied Folk Art]. In VARGA, Marianna - Szabó, Rózsa (eds.) Népi iparmüvészetünk idöszerü kérdései I, 103-114. Budapest: Népi Iparmüvészeti Tanács.

MAJOR, Máté

1953 Az épülő kommunizmus képzőmüvészete [Fine Arts in the Communism under Cconstruction]. Budapest: Hungarian - Soviet Society - Fine Arts Fund.

NAGY, László

1980 Háziipari és Népi Iparmüvészeti Szövetkezetek [Cottage Industry and Folk Industrial Arts Co-operatives]. Budapest: Népi Iparművészeti Tanács.

1983 A magyar népi iparmüvészet harminc éve [Thirty Years of Hungarian Applied Folk Art]. Budapest: Népi Iparmüvészeti Tanács - Néprajzi Múzeum.

Ö. KovÁcs, József

2013 The Liquidation of Traditional Peasant Society in Hungary 1948-1961. Acta Ethnographica Hungarica 58(1):3-19.

Puskásné OlÁH, Júlia

1992 Országos Népmüvészeti Kiállitások Gránátalma Díjas Alkotásai [Pomegranade Awarded Artifacts on the National Folk Arts Exhibitions]. Nyíregyháza: Váci Mihály Városi Müvelődési Központ.

PÜNKÖsTI, Árpád

2004 Rákosi Mátyásné, a keramikus [Mrs. Rákosi, the Ceramist]. Artportal. https:// artportal.hu/magazin/rakosi-matyasne--a-keramikus/ (accessed January 15, 2020) 
RAINER M., János

2014 A Kádár korszak kompromisszumai [Compromises in the Kádár-era]. In GeRö, András (ed.) Kompromisszumok a közép-európai politikai kultúrában, 61-73. Budapest: Közép- és Kelet-európai Történelem és Társadalom Kutatásáért Közalapítvány.

REZNICSEK, László - VinCze, Anita

2002 Palóc Népmúvészeti és Háziipari Szövetkezet, Szécsény. [Palóc Folk Arts and Cottage Industry Co-operative, Szécsény.] In KaPros, Márta - LenGYeL, Ágnes - Limbacher, Gábor (eds.) A Nógrád Megyei Múzeumok Évkönyve XXVI, 455-458. Balassagyarmat - Salgótarján: Nógrád Megyei Múzeumok Igazgatósága.

RoMsics, Imre

2003 A népmüvészet és a népi iparmüvészet a kalocsai népmüvészet példáján [Folk art and Applied Folk art on the Example of the Kalocsa Folk Art]. In FEJös, Zoltán (ed.) Néprajzi jelenkutatás és a múzeumi gyüjtemények változása Madok-füzetek 1, 29-39. Budapest: Néprajzi Múzeum.

SCHNEIDER, János

1985 A Népmüvészeti és Háziipari Szövetkezeti Vállalat jelene az elmúlt 35 év. [The Presence of the Folk Arts and Cottage Industry Co-operative Companies is the past 35 years]. Kereskedelmi Szemle XXVI(1):54-55.

SCHUBERT, Ernő - Balassa, Iván (eds.)

1953 Népmüvészeti és Iparmüvészeti Kiállitás [Folk Arts and Applied Arts Exhibition]. Budapest: Egyetemi Nyomda.

SzABó, Zoltán

2013 Tárgyak - alkotók - minőség - hitelesség. A nép iparmüvészet jelene és jövője [Objects, Creators, Quality and Credibility. Presence and Future of Applied Folk Art]. In ILLÉs, Vanda (ed.) A népi iparmüvészeti alkotások minősitésének szempontrendszere, 9-13. Budapest: Hagyományok Háza.

SzILÁGYI, Miklós

2005 Tendenciák, átalakulási folyamatok a népi iparmüvészetben [Tendencies and Transformation Processes in Applied Folk Art]. Ethnographia CXVI(3):321328.

2006 A kisipar népmüvészetté válásának körülményei és következményei [Circumstances and Consequences of Handicrafts Becoming Folk Art]. In Petercsák, Tivadar (ed.) Agria XLII, 263-274. Eger: Dobó István Vármúzeum.

SzULOVSzKY, János

2017 Búcsú a népművészettől [Farewell to Folk Art]. In SzulovszKy, János CzöveK, Judit (eds.) Közvetítö. Tanulmányok Hoppál Mihály 75. születésnapjára, 239-256. Budapest: Magyar Vallástudományi Társaság.

VALUCH, Tibor

2006 Hétköznapi élet Kádár János korában [Everyday Life in the Time of János Kádár]. Budapest: Corvina Kiadó.

2013 Magyar hétköznapok [Hungarian Everydays]. Fejezetek a mindennapi élet történetéből Magyarországon a második világháborútól napjainkig Budapest: Napvilág Kiadó. 
VARGA, Marianna

1980 A Népi Iparmúvészek szakmai képzésének formái [Forms of Vocational Trainings for Applied Folk Artists]. In VARGA, Marianna - SzABó, Rózsa (eds.) Népi iparmüvészetünk idöszerü kérdései I, 115-124. Budapest: Népi Iparművészeti Tanács.

2006 A matyó hímzés mint népmüvészeti és népi iparmüvészeti tárgy [Matyó Embroidery as a Folk Art- and Applied Folk Art Object]. In ViszócZKY, Ilona (ed.) Eredmények és feladatok a matyóság néprajzi kutatásában, 195-210. Miskolc - Mezőkövesd: Herman Ottó Múzeum.

VARGA, Zsuzsanna

2018 Az Új Gazdasági Mechanizmus elfeledett sikertörténete: a termelöszövetkezeti szektor [Forgotten Success Story of the New Economic Mechanism: the Agricultural Co-operative Sector]. Betekintö (12)2. http://www.betekinto.hu/ sites/default/files/betekinto-szamok/2018_2_varga_zs.pdf (accessed January $15,2020)$

VEREBÉLYI, Kincső

2002 Korok és stílusok a magyar népmüvészetben [Periods and Styles in Hungarian Folk Art]. Budapest: Osiris.

2003 Tárgyilagos megjegyzések a népmüvészetről [Objective Remarks on Folk Art]. In FEJős, Zoltán (ed.) Néprajzi jelenkutatás és a múzeumi gyüjtemények változása. (Madok-füzetek 1), 25-28. Budapest: Néprajzi Múzeum.

2019 Nép - Ipar-Müvészet [Folk-Applied-Art]. Studia Folkloristica et Ethnologia 73. Debrecen: Debreceni Egyetem Néprajzi Tanszék - Debreceni Egyetemi Kiadó.

VISZÓCZKY, Ilona

2003 Néhány adalék a Matyó Múzeum hímzéseinek vizsgálatához [Contributions to the Study of Embroidery in the Matyó Museum]. In VerEs, László - VIGA, Gyula (eds.) A Herman Ottó Múzeum Évkönyve XLII, 668-675. Miskolc: Herman Ottó Múzeum.

WEINER, Mihályné

1952 Felszabadult iparmüvészet [Liberated Applied Art]. Budapest: Művelt Nép Könyvkiadó.

\section{ABBREVIATION OF THE ARCHIVES USED FOR THE ANNOTATIONS OF THE PUBLIC RECORDS}

BFL: Budapest City Archives

BKML: Hungarian National Archives Bács-Kiskun County Archives

BML: Hungarian National Archives Békés County Archives

BAZML: Hungarian National Archives Borsod-Abaúj-Zemplén County Archives

CsML: Hungarian National Archives Csongrád County Archives

HBML: Hungarian National Archives Hajdú-Bihar County Archives

HML: Hungarian National Archives Heves County Archives

JNSzML: Hungarian National Archives Jász-Nagykun-Szolnok County Archives

NML: Hungarian National Archives Nógrád County Archives 
PML: Hungarian National Archives Pest County Archives

SML: Hungarian National Archives Somogy County Archives

SzSzBML: Hungarian National Archives Szabolcs-Szatmár-Bereg County Archives

TML: Hungarian National Archives Tolna County Archives

VaML: Hungarian National Archives Vas County Archives

VeML: Hungarian National Archives Veszprém County Archives

Bence Ament-Kovács is a junior research fellow in the Department of Historical Ethnology of the Institute of Ethnology, Research Centre for the Humanities, Excellent MTA Institute, a student at the PhD program of the Eötvös Loránd University entitled Hungarian and Comparative Folklore. His field of interest is divided between two key directions. In his doctoral thesis he deals with the historical ethnology of the German minorities (Danube Schwabians) in the South of Hungary in the $18^{\text {th }}$ century, that of the 'Swabians along the River Danube', and additionally - as a former museoligist of the Hungarian Museum of Folk Industrial Arts - he also carries out research projects in the field of the cottage industry organizations with a profile in folk industrial art. For this activity, he was recognized with the Prima Junior Award in 2016. E-mail: kovacs.bence@ btk.mta.hu

Open Access. This is an open-access article distributed under the terms of the Creative Commons Attribution 4.0 International License (https://creativecommons.org/licenses/by/4.0), which permits unrestricted use, distribution, and reproduction in any medium, provided the original author and source are credited, a link to the CC License is provided, and changes - if any - are indicated. (SID_1) 
